\title{
2. NEOGENE CALCAREOUS NANNOFOSSILS FROM SITES 811 AND 819 THROUGH 825, OFFSHORE NORTHEASTERN AUSTRALIA ${ }^{1}$
}

\author{
Wuchang Wei ${ }^{2}$ and Stefan Gartner ${ }^{3}$
}

\begin{abstract}
Calcareous nannofossils are generally abundant at the Queensland Trough transect sites (811 and 819 through 825 ) of Leg 133 , and they provide the primary means of dating the Neogene sediments. Sites 819 through 821 to the east of the Great Barrier Reef yielded abundant, moderately preserved Pleistocene nannofossils. The sections are biostratigraphically complete, except for a very condensed interval or a hiatus in the middle Pleistocene section at Site 819. A similar hiatus has been identified at Site 822, where abundant, well-preserved upper Pliocene through Holocene nannofossils were recovered. Abundant and well-preserved nannofossils at Site 823 provide a fairly high-resolution biostratigraphy for the upper Miocene-Holocene sediments recovered, which is remarkable for this turbidite-ridden sequence. Calcareous nannofossils diminish as preservation deteriorates abruptly downhole at Sites 811, 824, and 825 on the Queensland Plateau, and the nannofossil biostratigraphy for the Pliocene and Miocene intervals is only marginally useful.

Preservation of calcareous nannofossils varies greatly among different sites and is controlled by the amount of clay and bank-derived metastable aragonite and high-magnesium calcite in the sediments. Strong dissolution of upper Pleistocene calcareous nannofossils deposited in relatively shallow water and buried at shallow depth is documented for the first time.
\end{abstract}

\section{INTRODUCTION}

During Ocean Drilling Program (ODP) Leg 133, drilling was performed at 16 sites in the carbonate platform and troughs off the shore of northeastern Australia (Fig. 1) to understand the evolution of these large carbonate platforms and the adjoining basin and to investigate the effects of climate and sea level on their development through time. Calcareous nannofossils are generally abundant at all sites, and they provide the primary means of dating the sediments, particularly for the Pliocene-Pleistocene intervals. For the Miocene and upper Paleogene, where calcareous nannofossils are rare and poorly preserved, larger benthic foraminifers offer the most useful age information (Betzler, this volume). No useful magnetostratigraphic information could be extracted from Leg 133 cores because the original magnetic signals have been severely altered by diagenesis of the magnetic minerals (Omarzai, this volume).

This chapter presents the nannofossil biostratigraphy for Sites 811 and 819 through 825 on the Queensland Trough transect (Fig. 2). Major biostratigraphic results for these sites are summarized in Table 1 and discussed in detail below. Nannofossil biostratigraphy for Sites 812 through 818 and 826 on the Townsville Trough transect is provided in Gartner et al. (this volume).

In addition, this study discusses the effect of diagenesis on calcareous nannofossil preservation in sediments from the Queensland Trough transect sites and Deep Sea Drilling Project Site 209 (Fig. 1). Previously diagenesis of calcareous nannofossils was investigated by Schlanger and Douglas (1974), Neugebauer (1974), Matter et al. (1975), Wise (1977), and others. All these studies were concerned mainly with relatively deep water and deeply buried sediments of pre-Quaternary age. Roth and Berger (1975) reported dissolution and overgrowth on calcareous nannofossils from surface sediments taken mostly from depths ranging from 3500 to $4800 \mathrm{~m}$ in the South and Central Pacific Ocean. Winter (1982) showed calcite overgrowth in Emiliania huxleyi and Umbellosphaera irregularis in upper Pleisto-

\footnotetext{
${ }^{1}$ McKenzie, J.A., Davies, P.J., Palmer-Julson, A., et al., 1993. Proc. ODP, Sci. Results, 133: College Station, TX (Ocean Drilling Program).

${ }^{2}$ Scripps Institution of Oceanography, University of California at San Diego, La Jolla, CA 92093-0215, U.S.A. U.S.A.

${ }^{3}$ Department of Oceanography, Texas A\&M University, College Station, TX 77843.
}

cene sediments from the Red Sea. Here we show that strong dissolution of upper Pleistocene calcareous nannofossils can occur along with calcite overgrowth in sediments deposited in relatively shallow water and buried at shallow depth.

\section{METHODS}

One sample was taken from each core section aboard the ship. Smear slides were made directly from unprocessed samples and examined with a light microscope at a magnification of about $1250 \times$. The abundance of calcareous nannofossils on each slide was estimated using the following criteria: $\mathrm{V}=$ very abundant, more than 10 specimens per field of view; $A=$ abundant, $1-10$ specimens per field of view; $\mathrm{C}=$ common, 1 specimen per $2-10$ fields of view; $\mathrm{F}=$ few, 1 specimen per $11-50$ fields of view; $R=$ rare, 1 specimen per $51-200$ fields of view; $B=$ barren, no specimen was found in 200 fields of view. For preservation of nannofossil assemblages, the following notations are used: $\mathrm{G}$ = good, little evidence of etching or overgrowth; $\mathrm{M}=$ moderate, etching or overgrowth is apparent; $\mathrm{P}=$ poor, there is significant etching or overgrowth and identification of some species is impaired.

The calcareous nannofossil zonation of Okada and Bukry (1980) is used in this study (Fig. 3); however, a number of nannofossil datums not used in their zonation have been documented in this study. These include the beginning of the acme of Emiliania huxleyi, the last occurrence of Reticulofenestra sp. A Takayama and Sato (1987), the first occurrence of Gephyrocapsa spp. C-D Matsuoka and Okada (1990), the last occurrence of Gephyrocapsa spp. A-B Matsuoka and Okada (1990), the last occurrence of Helicosphaera sellii, the first and last occurrences of Amaurolithus amplificus, and the last occurrence of Catinaster calyculus. These additional datums allow higher biostratigraphic resolution than is possible with the formal zonation alone. The numerical ages for the nannofossil datums are taken mostly from the compilation of Berggren et al. (1985; see Fig. 3). Some were modified slightly, based on more recent studies (e.g., Gartner, 1992, unpubl. data).

Calcareous nannofossil species observed in this study are listed alphabetically by generic epithets in the appendix; the bibliographic references of these species can be found in Loeblich and Tappan (1966, 1968, 1969, 1970a, 1970b, 1971, 1973), van Heck (1979a, 1979b, 1980a, 1980b, 1981a, 1981b, 1982a, 1982b, 1983), and Steinmetz 


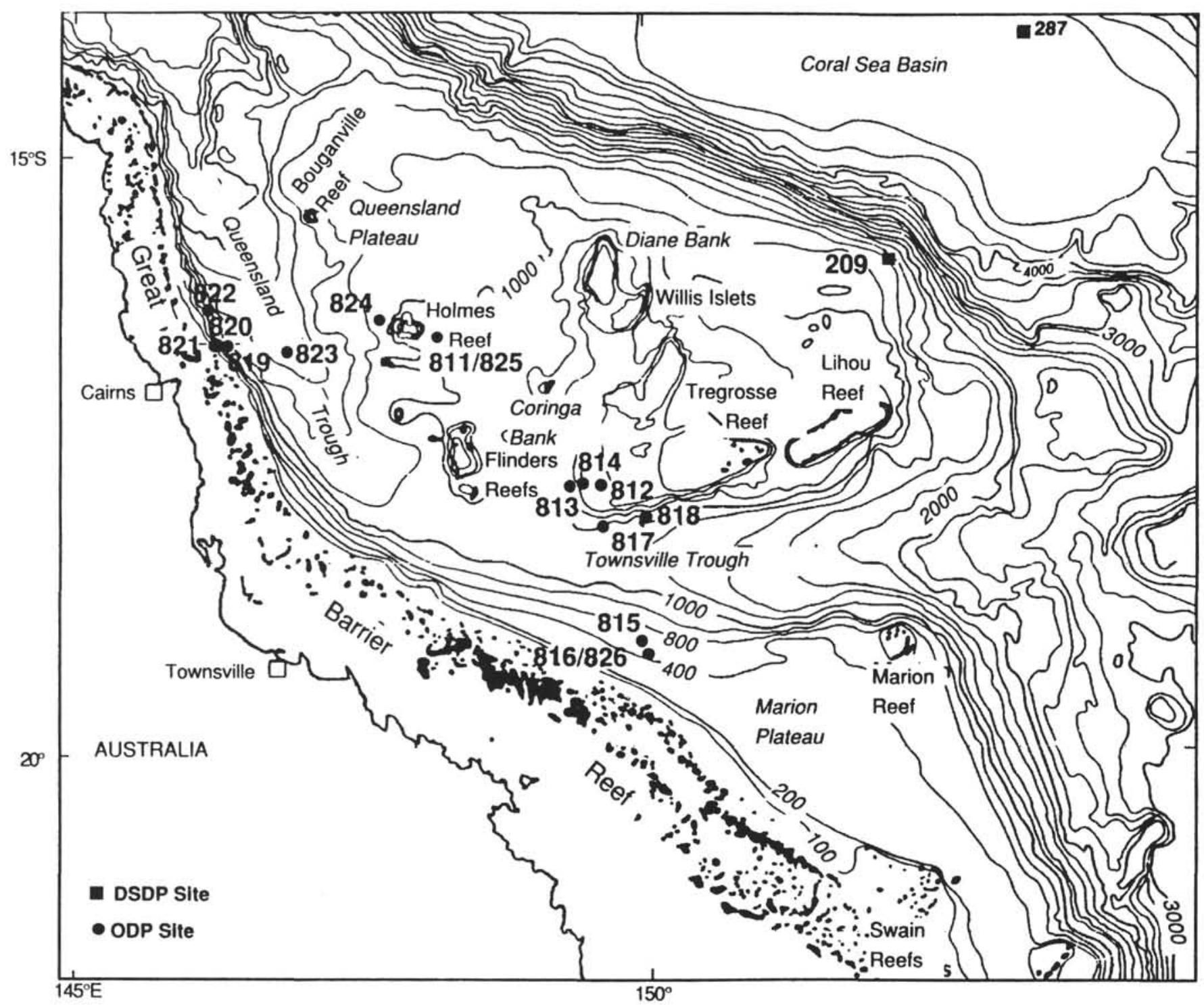

Figure 1. Map of northeastern Australian margin showing Leg 133 drill sites. Bathymetry in meters.

(1985a, 1985b, 1986, 1987a, 1987b, 1988a, 1988b, 1989). Selected nannofossil species are illustrated in Plates 1 and 2.

Diagenesis of calcareous nannofossils was investigated using a light microscope and a scanning electron microscope (SEM). Samples examined with the SEM were mounted on a cover glass glued to a specimen stub and coated with a thin film of gold-platinum alloy in a vacuum sputterer.

\section{NANNOFOSSIL BIOSTRATIGRAPHY}

\section{Site 811}

Calcareous nannofossils are abundant in the upper $170 \mathrm{~m}$ of the sequence recovered at Site 811. Preservation of nannofossils deteriorates rapidly downhole; consequently, the resolution of the nannofossil biostratigraphy (Fig. 4) also deteriorates downhole and the 170- to 380 -mbsf interval is practically unzonable by nannofossils.

Hole $811 \mathrm{~A}$ extends from 0 to $214.5 \mathrm{mbsf}$ and core recovery was nearly $100 \%$. Samples $133-811 \mathrm{~A}-1 \mathrm{H}-\mathrm{CC}$ through $-2 \mathrm{H}-2,112 \mathrm{~cm}$, contain Gephyrocapsa caribbeanica and other Pleistocene taxa, but no Emiliania huxleyi or Pseudoemiliania lacunosa, which constrains this interval to Subzone $\mathrm{CN} 14 \mathrm{~b}(0.275$ to $0.465 \mathrm{Ma})$. Rare $P$. lacunosa were observed from Sample 133-811A-2H-3, $112 \mathrm{~cm}$, downward. The last occurrence of $P$. lacunosa (placed between Samples 133$811 \mathrm{~A}-2 \mathrm{H}-2,112 \mathrm{~cm}$, and $-2 \mathrm{H}-3,112 \mathrm{~cm}$ ) defines the $\mathrm{CN} 14 \mathrm{a} / \mathrm{CN} 14 \mathrm{~b}$ boundary, which has an age of $0.465 \mathrm{Ma}$. Few Calcidiscus macintyrei and common Discoaster brouweri were first encountered in Sample $133-811 \mathrm{~A}-3 \mathrm{H}-6,112 \mathrm{~cm}$. This suggests that the sample is in Subzone $\mathrm{CN} 12 \mathrm{~d}(1.48$ to $1.88 \mathrm{Ma})$. This also suggests that the stratigraphic range of $C$. macintyrei is truncated, and an unconformity $(>0.4$ m.y.) is present between Samples 133-811A-3H-5, $112 \mathrm{~cm}$, and -3H-6, 112 $\mathrm{cm}$. This unconformity separates Pliocene and Pleistocene sediments.

The last occurrence of Discoaster pentaradiatus was determined between Samples 133-811A-4H-3, $112 \mathrm{~cm}$, and $-4 \mathrm{H}-4,112 \mathrm{~cm}$, where the species is rare. This datum marks the $\mathrm{CN} 12 \mathrm{c} / \mathrm{CN} 12 \mathrm{~d}$ subzonal boundary $(2.29 \mathrm{Ma})$. The next datum recognized is the last occurrence of Discoaster tamalis in Sample 133-811A-5H-3, $112 \mathrm{~cm}$, which defines the $\mathrm{CN} 12 \mathrm{~b} / \mathrm{CN} 12 \mathrm{a}$ subzonal boundary. The last occurrence of Discoaster surculus could not be used at this site because of poor preservation of the nannofossil assemblages in the Pliocene.

Rare specimens of Sphenolithus abies were found in Sample 133$811 \mathrm{~A}-8 \mathrm{H}-\mathrm{CC}$. The last occurrence of Reticulofenestra pseudoumbilicus is in Sample 133-811 A-9H-1, $114 \mathrm{~cm}$, where the species is abun- 


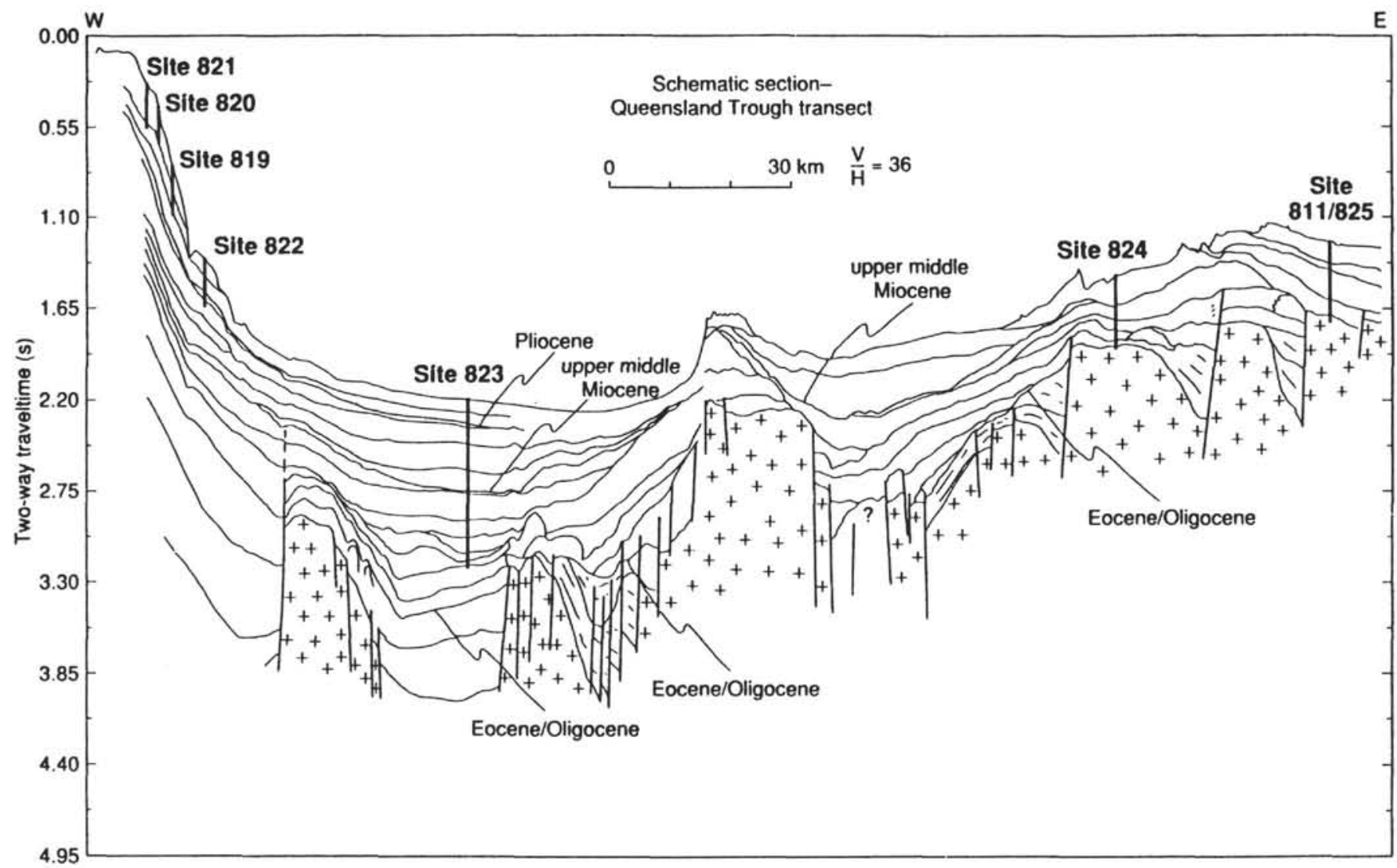

Figure 2. Schematic transect across the Queensland Trough.

dant. This datum has an age of $3.51 \mathrm{Ma}$ and marks the lower Pliocene/upper Pliocene boundary. Samples 133-811A-9H-4 and -9H-CC contain rare specimens of Amaurolithus tricorniculatus, and these samples are placed in Zone CN10. Zone CN11 is thus condensed (Fig. 4) and may contain an unconformity.

The last occurrence of Discoaster quinqueramus, which defines the Miocene/Pliocene boundary in terms of nannofossil biostratigraphy, is drawn between Samples 133-811A-10H-CC and -11 H-1, $113 \mathrm{~cm}$. One specimen of Amaurolithus amplificus was found in Sample 133-811A$11 \mathrm{H}-\mathrm{CC}$, and that level is dated as the lower part of Subzone CN9b (5.6-5.9 Ma, see Fig. 3). Rare specimens of Amaurolithus are present in Samples 133-811 A-11H-CC and -12H-CC, indicating an age younger than 6.74 Ma for these samples. Species of Amaurolithus are absent, whereas Discoaster quinqueramus is still present in Cores $133-811 \mathrm{~A}-13 \mathrm{H}$ and $-14 \mathrm{H}$. The first occurrence of D. quinqueramus is tentatively placed between Samples $133-811 \mathrm{~A}-15 \mathrm{H}-2,113 \mathrm{~cm}$, and $-15 \mathrm{H}-3,113 \mathrm{~cm}$, because it is difficult to determine the first occurrence of this species in the presence of transitional forms between this species and an earlier one, Discoaster bellus. The lowest datum identified in Hole 811A is the last occurrence of Discoaster hamatus in Core 811A-19H. Rare specimens of D. hamatus were found in Samples 133-811A-19H-5, $113 \mathrm{~cm}$, and-19H-CC. The species is absent in or above Sample 133-811A-19H-3, $113 \mathrm{~cm}$. Sample 133-811A-19H-4, $113 \mathrm{~cm}$, is virtually barren of calcareous nannofossils because of strong dissolution and reprecipitation. Consequently, the last occurrence of D. hamatus, which defines the CN7/CN8 zonal boundary, is drawn between Samples 133-811A-19H-3, $113 \mathrm{~cm}$, and $-19 \mathrm{H}-5,113 \mathrm{~cm}$.

Hole 811B was cored from 193.2 to $392.5 \mathrm{mbsf}$. Core recovery was very poor $(<8 \%)$ throughout the hole, with no sediment recovered from Cores 133-811B-1X, $-5 \mathrm{X},-6 \mathrm{X},-11 \mathrm{X},-13 \mathrm{X},-14 \mathrm{X}$, and $-22 \mathrm{X}$ through $-24 X$. Calcareous nannofossils are generally rare and poorly preserved in this hole. Sample 133-811B-8V-CC contains Calcidiscus premacin- tyrei. The range of this species has been correlated with magnetostratigraphy in the North Atlantic at 12.3 to $14.1 \mathrm{Ma}$ (Gartner, 1992). Samples 133-811B-10V-CC, -12X-CC, and -15X-CC are barren of nannofossils. Core-catcher samples from Cores 133-811B-16X through $-21 \mathrm{X}$ contain rare or few specimens of Cyclicargolithus floridanus and, sporadically, rare specimens of Sphenolithus moriformis and Coccolithus pelagicus. An age range of middle Eocene-middle Miocene can be assigned to these samples based on the occurrence of $C$. floridanus.

\section{Site 819}

One hole was drilled at Site 819, and an expanded Pleistocene section $(400 \mathrm{~m})$ was recovered. Calcareous nannofossils are abundant and generally moderately well preserved in most of the samples examined. Nannofossil biostratigraphy is summarized graphically in Figure 5.

Emiliania huxleyi is abundant in Samples 133-819A-1H-1, 112 $\mathrm{cm}$, through - $1 \mathrm{H}-5,112 \mathrm{~cm}$; common in Sample 133-819A-2H-1, 112 $\mathrm{cm}$; few or rare in Samples 133-819A-22H-3, $112 \mathrm{~cm}$, through - $4 \mathrm{H}-1$, $112 \mathrm{~cm}$; and absent in and below Sample 133-819A-4H-2, $112 \mathrm{~cm}$. The lower boundary of the Emiliania huxleyi Acme Zone (0.075 Ma) is between Samples $133-819 \mathrm{~A}-1 \mathrm{H}-5,112 \mathrm{~cm}$, and $-2 \mathrm{H}-1,112 \mathrm{~cm}$; the first occurrence of $E$. huxleyi $(0.275 \mathrm{Ma})$, which defines the CN14b/CN15 zonal boundary, is between Samples 133-819A-4H-1, $112 \mathrm{~cm}$, and $-4 \mathrm{H}-2,112 \mathrm{~cm}$. Samples 133-819A-4H-2, $112 \mathrm{~cm}$, and $-4 \mathrm{H}-3,112 \mathrm{~cm}$, contain abundant Gephyrocapsa oceanica and small Gephyrocapsa but no E. huxleyi or Pseudoemiliania lacunosa, and thus have been assigned to Subzone CN14b (0.275-0.465 Ma). Pseudoemiliania lacunosa occurs from Sample 133-819A-4H-4, 112 $\mathrm{cm}$, where it is abundant, downward throughout the hole. The lower boundary of Subzone CN14b defined by the last occurrence of $P$. lacunosa has been placed between Samples 133-819A-4H-3, $112 \mathrm{~cm}$, 
Table 1. Summary of age-mean depth (mbsf) information for the Queensland Trough transect sites.

\begin{tabular}{|c|c|c|c|c|c|c|c|c|c|}
\hline Datum & $\begin{array}{l}\text { Age } \\
(\mathrm{Ma})\end{array}$ & $\begin{array}{c}\text { Site } \\
811 \\
\text { depth }\end{array}$ & $\begin{array}{c}\text { Site } \\
819 \\
\text { depth }\end{array}$ & $\begin{array}{c}\text { Site } \\
820 \\
\text { depth }\end{array}$ & $\begin{array}{c}\text { Site } \\
821 \\
\text { depth }\end{array}$ & $\begin{array}{c}\text { Site } \\
822 \\
\text { depth }\end{array}$ & $\begin{array}{c}\text { Site } \\
823 \\
\text { depth }\end{array}$ & $\begin{array}{c}\text { Site } \\
824 \\
\text { depth }\end{array}$ & $\begin{array}{c}\text { Site } \\
825 \\
\text { depth }\end{array}$ \\
\hline FO E. huxleyi acme & 0.075 & & 8.4 & 12.1 & & & & & \\
\hline FO E huxleyi & 0.275 & & 29.4 & 35.8 & 39.3 & 21.8 & 12.2 & & \\
\hline LO P. lacunosa & 0.465 & 8.9 & 32.4 & 107.1 & 123.1 & 21.8 & 32.0 & 47.8 & \\
\hline LO R. sp. A & 0.81 & & & & & 54.8 & & & \\
\hline FO G. spp. C-D & 0.92 & & 56.1 & 163.6 & 176.8 & 77.8 & 80.2 & & \\
\hline LO G. spp. A-B & 1.10 & & 166.9 & 260.3 & 270.1 & 125.6 & 95.5 & & \\
\hline LOH. sellii & 1.27 & & 189.2 & 271.7 & 279.2 & 220.0 & 105.7 & & \\
\hline LO C. macintyrei & 1.48 & 22.9 & $>400$ & $>400$ & $>400$ & 301.5 & 150.9 & 92.8 & \\
\hline LO D. brouweri & 1.88 & 22.9 & & & & 333.4 & 163.0 & & \\
\hline LO D. pentaradiatus & 2.29 & 29.4 & & & & 399.3 & 222.3 & & \\
\hline LO D. surculus & 2.42 & & & & & 411.0 & 236.2 & & \\
\hline LO D. tamalis & 2.60 & 38.9 & & & & 419.0 & 244.3 & & \\
\hline LO R. pseudoumbilicus & 3.51 & 72.6 & & & & & 359.3 & & \\
\hline FO D. asymmetricus ac. & 3.88 & & & & & & 435.5 & & \\
\hline LO A. tricorniculatus & 4.24 & 76.9 & & & & & 521.6 & & \\
\hline LO $C$. armatus & 4.60 & & & & & & 602.0 & & \\
\hline LO D. quinqueramus & 5.26 & 91.6 & & & & & 653.0 & & \\
\hline LO A. amplificus & 5.6 & & & & & & 733.1 & & \\
\hline FO A. amplificus & 5.9 & & & & & & 767.6 & & \\
\hline FO D. quinqueramus & 8.2 & 132.6 & & & & & 967.4 & & \\
\hline LO C. calyculus & 8.75 & & & & & & 971.9 & & \\
\hline LO D. hamatus & 8.85 & 172.6 & & & & & & & \\
\hline LO C. coalitus & 9.0 & & & & & & 989.8 & & \\
\hline FO C. coalitus & 10.8 & & & & & & 1009.1 & & \\
\hline LO C. floridanus & 11.0 & & & & & & & & 214.3 \\
\hline
\end{tabular}

Note: $\mathrm{LO}=$ last occurrence $\mathrm{FO}=$ first occurrence.

and $-4 \mathrm{H}-4,112 \mathrm{~cm}$. Subzone $\mathrm{CN} 14 \mathrm{~b}$ is very thin, and a significant amount of sediment appears to be missing.

Gephyrocapsa spp. C-D Matsuoka and Okada (1990) are common or abundant in Cores 133-819A-1 H through -6H. The first occurrence of these taxa $(0.92 \mathrm{Ma})$ is between Samples $133-819 \mathrm{~A}-6 \mathrm{H}-6,112 \mathrm{~cm}$, and $-7 \mathrm{H}-1,112 \mathrm{~cm}$. Gephyrocapsa spp. A-B Matsuoka and Okada (1990) occur from Sample 133-819A-20X-1, $112 \mathrm{~cm}$, downward. Because preservation of nannofossils is generally poor in Cores 133-819A-15X through -21X, the bridge in some of the Gephyrocapsa spp. A-B specimens may have been destroyed, rendering these specimens indistinguishable from small specimens of Reticulofenestra. Consequently, the last occurrence of Gephyrocapsa spp. A-B drawn between Samples 133-819A-19X-3, $112 \mathrm{~cm}$, and -21X-1, 112 $\mathrm{cm}$, is considered less reliable.

No sediment was recovered from Core 133-819A-22X. The last occurrence of Helicosphaera sellii was found in Sample 133-819A23X-CC. Rare to few specimens of this species also were found in Samples 133-819A-24X-CC, -26X-CC, -27X-CC, -33X-CC, -42XCC, $-43 \mathrm{X}-\mathrm{CC}$, and $-44 \mathrm{X}-\mathrm{CC}$. Based on the presence of this species in the absence of Calcidiscus macintyrei in Cores 133-819A-23X through $-44 \mathrm{X}-\mathrm{CC}$, this interval is dated as $1.27-1.48 \mathrm{Ma}$.

\section{Site 820}

Two holes were drilled at Site 820 ; Hole $820 \mathrm{~A}$ extends from 0 to $144 \mathrm{mbsf}$, and Hole $820 \mathrm{~B}$ extends from 0 to $400 \mathrm{mbsf}$. As at Site 819 , an expanded Pleistocene section $(400 \mathrm{~m})$ was recovered at Site 820 . The sediments are rich in calcareous nannofossils. Preservation of nannofossils is generally good for the upper $40 \mathrm{~m}$ and moderate to poor for the lower sequence. A summary of the nannofossil biostratigraphic results is presented in Figure 6.

Emiliania huxleyi is abundant in Samples 133-820A-1H-1, 112 $\mathrm{cm}$, through $-2 \mathrm{H}-3,112 \mathrm{~cm}$; few or rare in Samples 133-820A-2H-4, $112 \mathrm{~cm}$, through $-4 \mathrm{H}-6,112 \mathrm{~cm}$; and absent from Sample 133-820A$5 \mathrm{H}-1,112 \mathrm{~cm}$, downward. The lower boundary of the Emiliania huxleyi Acme Zone ( $0.075 \mathrm{Ma})$ is drawn between Samples 133-820A$2 \mathrm{H}-3,112 \mathrm{~cm}$, and $-2 \mathrm{H}-4,112 \mathrm{~cm}$; the lower boundary of Zone CN15 (the first occurrence of $E$. huxleyi, $0.275 \mathrm{Ma}$ ) is placed between
Samples $133-820 \mathrm{~A}-4 \mathrm{H}-6,112 \mathrm{~cm}$, and $-5 \mathrm{H}-1,112 \mathrm{~cm}$. Species present in these four cores include rare Calcidiscus leptoporus, abundant Gephyrocapsa oceanica and Gephyrocapsa spp. (small), few-to-rare Helicosphaera carteri, Scapholithus fossilis, Syrocosphaera pulchra, and Umbellosphaera irregularis.

Rare specimens of Pseudoemiliania lacunosa were first encountered in Sample 133-820A-12H-4, $110 \mathrm{~cm}$; medium- to large-sized Gephyrocapsa (Gephyrocapsa spp. C-D Matsuoka and Okada, 1990) are common in this sample through Sample $133-820 \mathrm{~A}-15 \mathrm{H}-4,110 \mathrm{~cm}$. Thus, the interval from Samples $133-820 \mathrm{~A}-12 \mathrm{H}-4,110 \mathrm{~cm}$, to $-15 \mathrm{H}-4$, $110 \mathrm{~cm}$, is dated as 0.465 to $0.92 \mathrm{Ma}$. Samples $133-820 \mathrm{~B}-18 \mathrm{H}-3$, $112 \mathrm{~cm}$, through $-28 \mathrm{X}-6,112 \mathrm{~cm}$, contain abundant small Gephyrocapsa, although large- or medium-sized Gephyrocapsa are virtually absent. This interval has an age of $0.92-1.10 \mathrm{Ma}$.

Gephyrocapsa spp. A-B Matsuoka and Okada (1990) occur from Sample 133-820B-28X-CC downward to the bottom of the hole. The last occurrence of Gephyrocapsa spp. A-B (1.10 Ma) is placed between Samples 133-820B-28X-6, $112 \mathrm{~cm}$, and -28X-CC.

The last occurrence of Helicosphaera sellii $(1.27 \mathrm{Ma})$ is placed between Samples 133-820B-29X-CC and -30X-2, $110 \mathrm{~cm}$, based on the absence of the species in and above Sample 133-820B-29X-CC and the rare occurrences of this species in Samples 133-820B-30X-2, $110 \mathrm{~cm}$, and $-30 \mathrm{X}-\mathrm{CC}$, and in several samples further downhole. The next lower biostratigraphic marker, the last occurrence of Calcidiscus macintyrei (1.48 Ma), was not encountered in the hole. This suggests that the bottom of the hole (Sample 133-820B-44X-CC) did not penetrate into the lowermost Pleistocene and is younger than $1.48 \mathrm{Ma}$.

\section{Site 821}

Site 821 is the shallowest of the three sites on the slope transect (Fig. 2) to the east of the Great Barrier Reef. At Site 821, as at the other two sites ( 819 and 820 ) on the slope, an expanded Pleistocene section was recovered (Fig. 7). Calcareous nannofossils are abundant, and preservation is moderate to poor except in some clayey intervals where preservation is excellent.

Emiliania huxleyi are present in Samples 133-821A-1H-1, $112 \mathrm{~cm}$, through -3H-1, $111 \mathrm{~cm}$. This species is rare in Samples 133-821A-3H-2, 


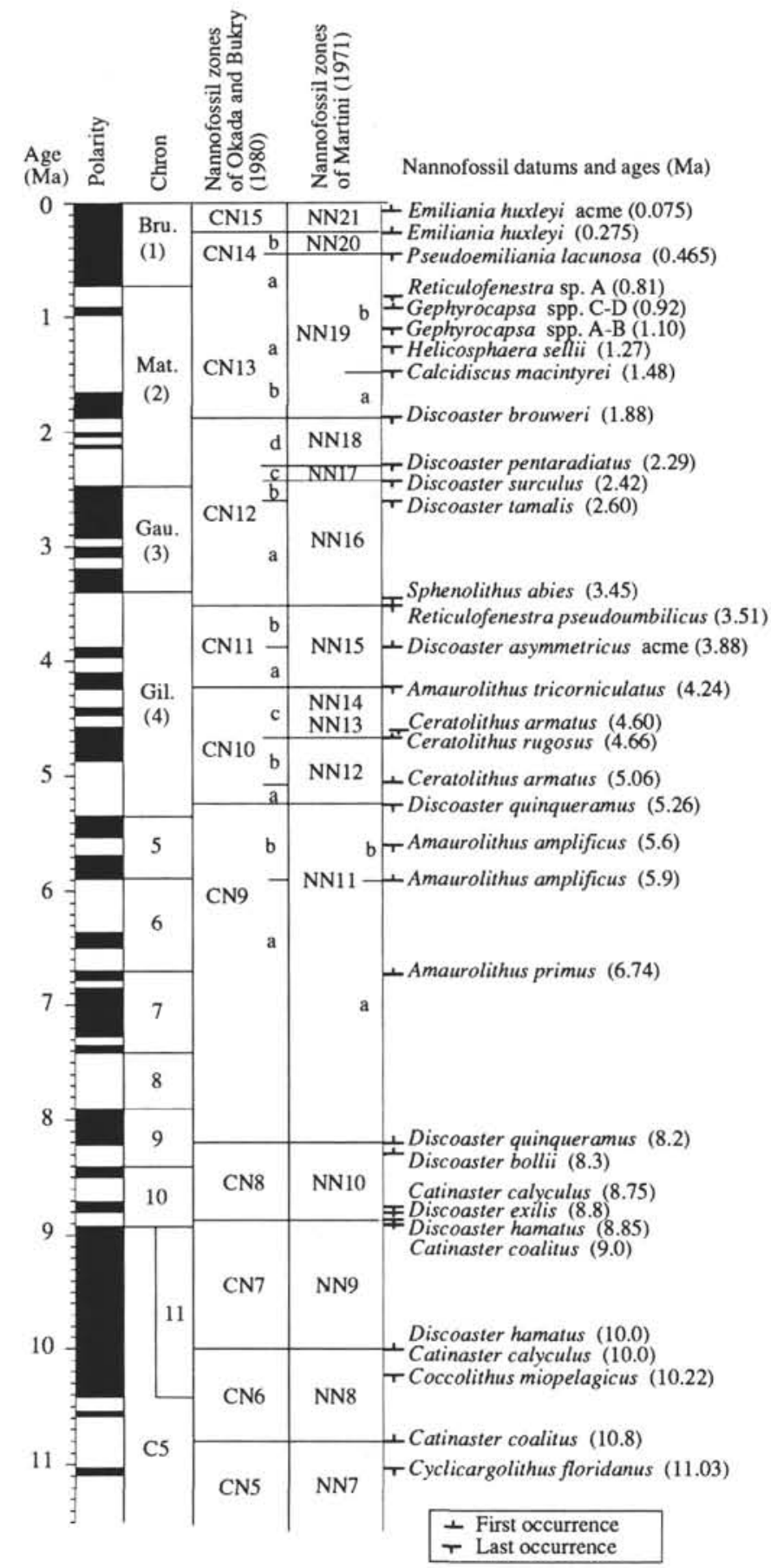

Figure 3. Calcareous nannofossil zonation and datums used here and their ages as calibrated with the geomagnetic polarity time scale of Berggren et al. (1985).

$111 \mathrm{~cm}$, through $-5 \mathrm{H}-4,111 \mathrm{~cm}$, and absent from Sample 133-821A$5 \mathrm{H}-5,111 \mathrm{~cm}$, downward. The Emiliania huxleyi Acme Zone cannot be identified in this section because of the generally low abundance of this species. The first occurrence of E. huxleyi $(0.275 \mathrm{Ma})$ is between Samples 133-821A-5H-4, $111 \mathrm{~cm}$, and $-5 \mathrm{H}-5,111 \mathrm{~cm}$. The last occurrence of Pseudoemiliania lacunosa is in Sample 133-821A-14H-4, $112 \mathrm{~cm}$, and the interval between this datum and the previous one is assigned to Subzone CN14b, with an age range of $0.275-0.465 \mathrm{Ma}$.

Gephyrocapsa spp. C-D Matsuoka and Okada (1990) are common or abundant down to Sample 133-821A-20X-1, $112 \mathrm{~cm}$, and are rare or absent from Sample 133-821A-20X-2, $112 \mathrm{~cm}$, downward. An age

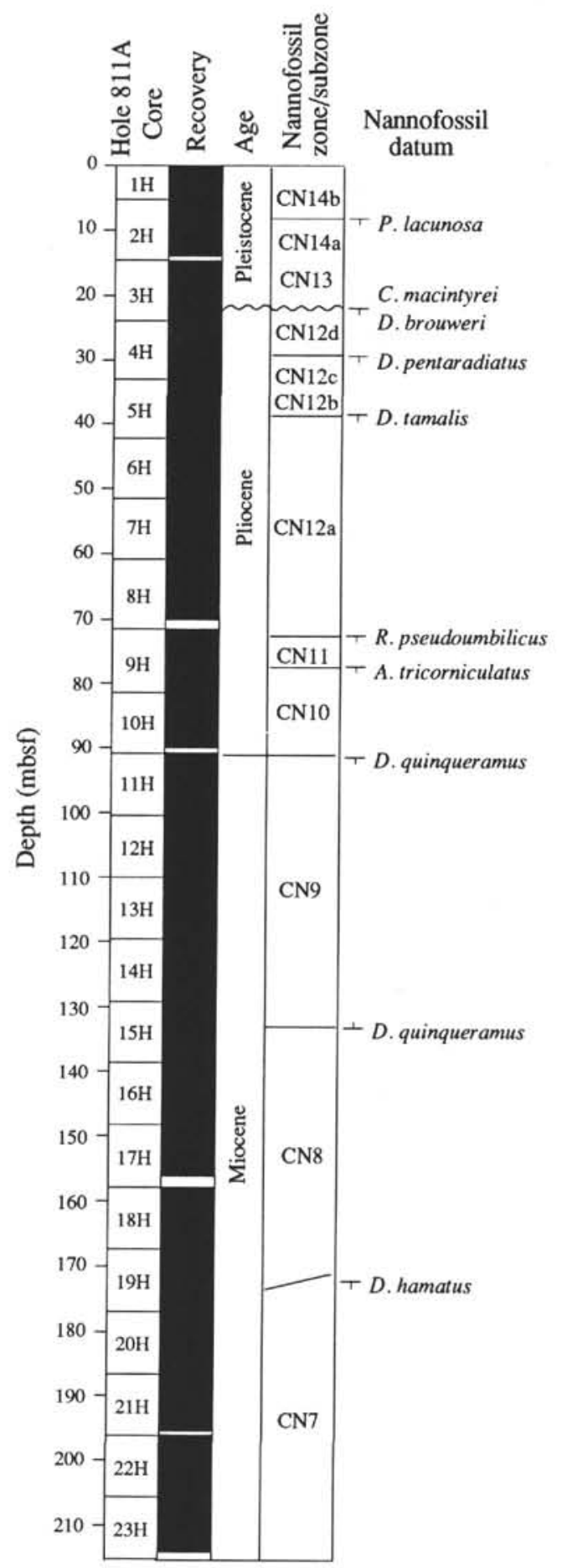

Figure 4. Calcareous nannofossil biostratigraphy, Hole 811A.

of 0.92 Ma can be assigned between Samples 133-821A-20X-1, 112 $\mathrm{cm}$, and $-20 \mathrm{X}-2,112 \mathrm{~cm}$, based on the first occurrence of Gephyrocapsa spp. C-D there. The interval from Samples 133-821A-20X-2, $112 \mathrm{~cm}$, to $-29 \mathrm{X}-5,116 \mathrm{~cm}$, contains dominantly small Gephyrocapsa (mostly 2-3 mm) with a virtual absence of large- or medium-sized Gephyrocapsa. The last occurrence of Gephyrocapsa spp. A-B Matsuoka and Okada (1990) is in Sample 133-821 A-30X-1, 112 cm, which has an age of $1.10 \mathrm{Ma}$. The next lower datum is the highest occurrence of Helicosphaera sellii between Samples 133-821A-30X-5, $112 \mathrm{~cm}$, and $-30 \mathrm{X}-\mathrm{CC}$, and this level has an age of $1.27 \mathrm{Ma}$. The last occurrence 


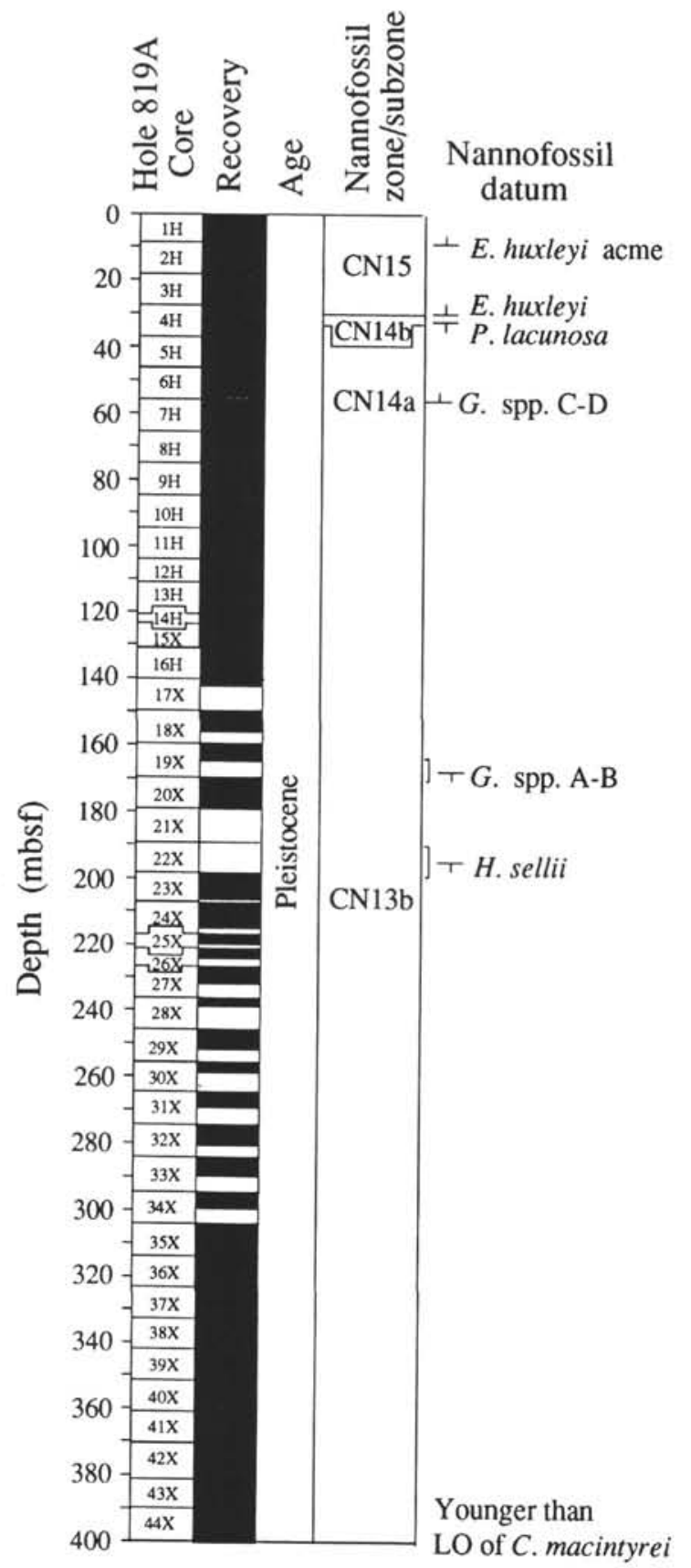

Figure 5. Calcareous nannofossil biostratigraphy, Hole 819A.

of Calcidiscus macintyrei (1.48 Ma) was not observed in the oldest sediment recovered at Site 821, and this indicates an age between 1.27 and 1.48 Ma.

\section{Site 822}

Site 822 penetrated $434 \mathrm{~m}$ of sediments and recovered an expanded Holocene to upper Pliocene section of hemipelagic sediments. Calcareous nannofossils are generally abundant and well preserved throughout the sequence. The distribution of nannofossil taxa at Site 822 is documented in Table 2.

Emiliania huxleyi occurs from Samples 133-822A-1H-CC to -4H-1, $113 \mathrm{~cm}$; this interval is assigned to the Emiliania huxleyi Zone (CN15, $0-0.275 \mathrm{Ma})$. The abundance of $E$. huxleyi fluctuates greatly in this

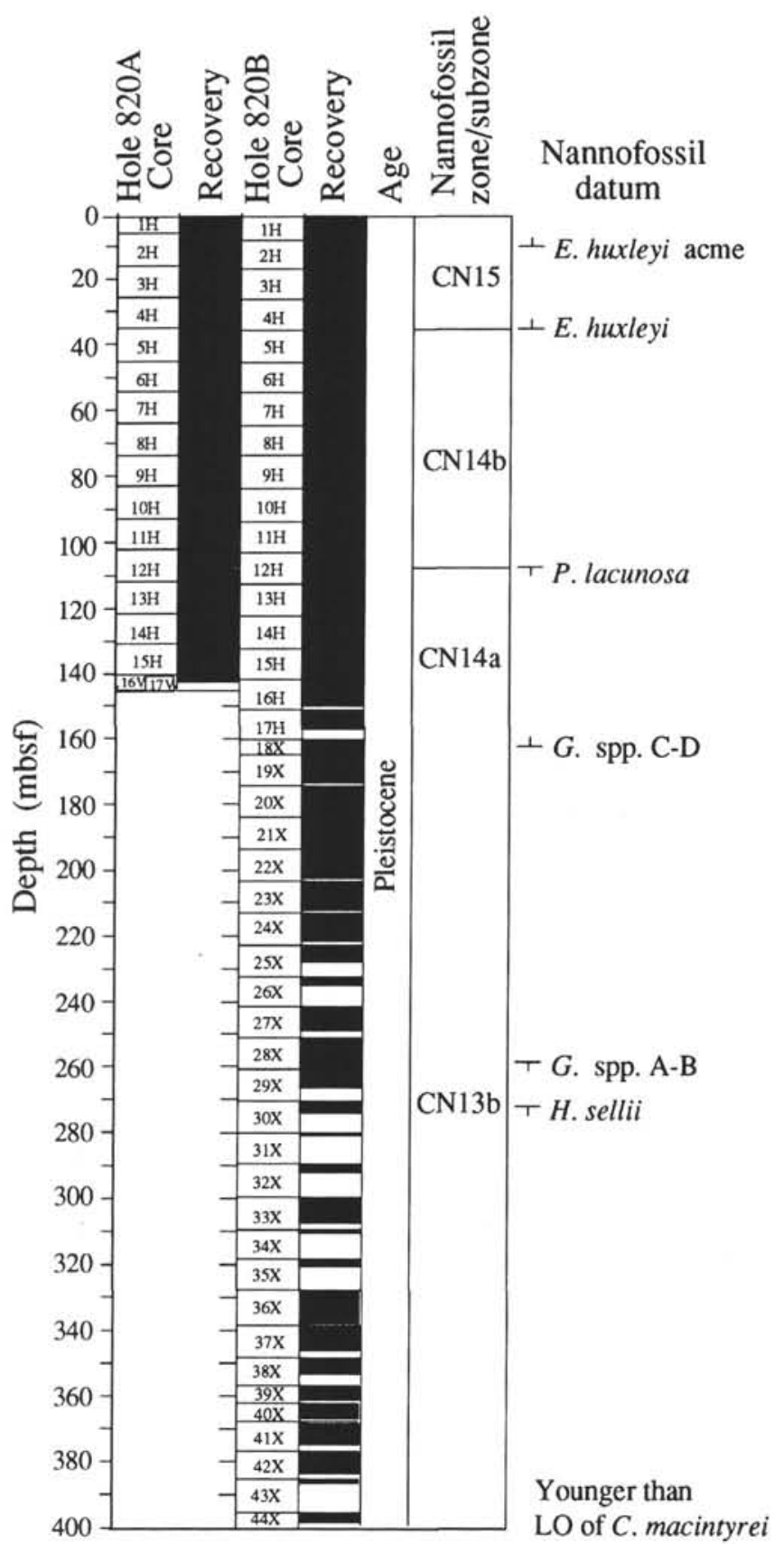

Figure 6. Calcareous nannofossil biostratigraphy, Site 820.

interval, and it is not possible to identify the Emiliania huxleyi Acme Zone. The absence of this species in Sample 133-822A-2H-1, $112 \mathrm{~cm}$, is unusual, and it may be because of a sediment slump of Subzone $\mathrm{CN} 14 \mathrm{~b}$ from upslope. A slump of sediment of other ages would have yielded a different assemblage easily detectable by our analysis. The highest occurrence of Pseudoemiliania lacunosa is in Sample 133$822 \mathrm{~A}-4 \mathrm{H}-2,113 \mathrm{~cm}$. This suggests that Subzone CN14b $(0.275$ to $0.465 \mathrm{Ma})$ is missing because of an unconformity.

The next lower datum recognized is the last occurrence of Reticulofenestra sp. A (see Pl. 2, Figs. 3, 8, and 9) Takayama and Sato (1987) in Sample 133-822A-7H-5, $113 \mathrm{~cm}$. This datum has an age of about $0.81 \mathrm{Ma}$ as calibrated with magnetostratigraphy (Takayama and Sato, 1987; Matsuoka and Okada, 1989) and oxygen isotope stratigraphy at a number of sites (W. Wei, unpubl. data). The first occurrence of Gephyrocapsa spp. C-D Matsuoka and Okada (1990), which has an 


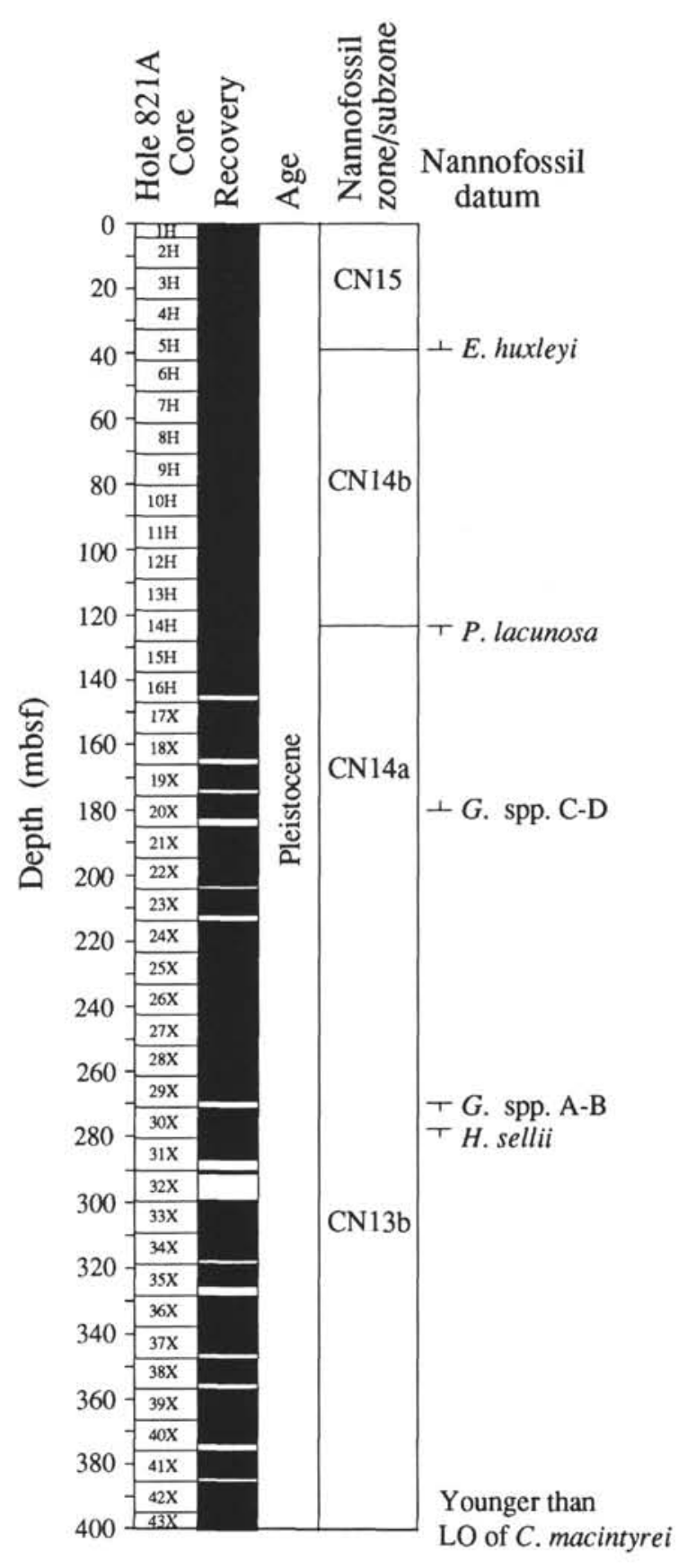

Figure 7. Calcareous nannofossil biostratigraphy, Hole $821 \mathrm{~A}$.

age of $0.92 \mathrm{Ma}$, is in Sample 133-822A-9H-CC, where the species is abundant. Gephyrocapsa protohuxleyi is very abundant $(50 \%-80 \%$ of the assemblage) in Samples $133-822 \mathrm{~A}-10 \mathrm{H}-2,113 \mathrm{~cm}$, through $-13 \mathrm{H}-$ $\mathrm{CC}$, and this species was verified by SEM (see Pl. 1, Figs. 4 and 5). Apparently, an acme of this species occurred at about 1.0 Ma. This finding is at variance with that of Matsuoka and Okada $(1989,1990)$, who correlated the event to the Brunhes/Matuyama boundary at about 0.73 Ma. The first occurrence of Reticulofenestra sp. A Takayama and Sato (1987) is in Sample 133-822A-11H-3, $111 \mathrm{~cm}$. Reticulofenestra asanoi, a circular variant of $R$. sp. A, was found in only one sample (133-822A$10 \mathrm{H}-2,114 \mathrm{~cm}, \mathrm{Pl} .2$, Fig. 4), although this species is common in the Arabian Sea and was used there as an index fossil (Sato et al., 1991).

The last occurrence of Gephyrocapsa spp. A-B Matsuoka and Okada (1990) is in Sample 133-822A-15X-1, $112 \mathrm{~cm}$; this sample has an age of 1.10 Ma. Rare specimens of Helicosphaera sellii are present in Sample 133-822A-25X-1, $37 \mathrm{~cm}$, and in a number of samples downhole. An age of 1.27 Ma can be assigned to Sample 133-822A-15X-1, $112 \mathrm{~cm}$. The next lower datum, the last occurrence of Calcidiscus macintyrei (1.48 Ma) is between Samples 133-822A-33X-2, $112 \mathrm{~cm}$, and $-33 \mathrm{X}-3,112 \mathrm{~cm}$. This datum is followed by the last occurrence of Discoaster brouweri (1.88 Ma) in Sample 133-822A-36X-5, $110 \mathrm{~cm}$, where the species is common. The last occurrence of Discoaster pentaradiatus $(2.29 \mathrm{Ma}$ ) is in Sample 133-822A-43X-CC, followed by the last occurrence of Discoaster surculus (2.42 Ma) in Sample 133-822A-45X$5,112 \mathrm{~cm}$. The last datumencountered is the last occurrence of Discoaster tamalis $(2.60 \mathrm{Ma})$ in Sample 133-822A-45X-CC. The oldest sediment from Site 822 has an age of older than $2.60 \mathrm{Ma}$ but younger than 3.45 $\mathrm{Ma}$, based on the presence of $D$. tamalis in the absence of Sphenolithus abies and Reticulofenestra pseudoumbilicus.

\section{Site 823}

Three holes were drilled at Site 823; Hole 823A extends from 0 to $120 \mathrm{mbsf}$; Hole 823B duplicates Hole 823A for the upper $120 \mathrm{~m}$ and extends to $805 \mathrm{mbsf}$; Hole 823 C cored from 784 to $1011 \mathrm{mbsf}$ (Fig. 8). Calcareous nannofossils are generally abundant and well preserved in the Holocene through upper Miocene sediments recovered at Site 823 . Virtually all of the conventional nannofossil markers for the interval were found, which enables a fairly high-resolution biostratigraphy (Fig. 8).

The first occurrence of Emiliania huxleyi is in Sample 133-823A$2 \mathrm{H}-4,115 \mathrm{~cm}$; this datum defines the lower boundary of Zone CN15 $(0.275 \mathrm{Ma})$. Emiliania huxleyi is generally rare in this interval, except in Samples 133-823A-1H-1, $113 \mathrm{~cm}$, and $-2 \mathrm{H}-2,115 \mathrm{~cm}$, where it is common to abundant. Consequently, it is not possible to identify the Emiliania huxleyi Acme Zone. Florisphaera profunda is most conspicuous in Zone CN15 at Site 823 , because it constitutes $70 \%-90 \%$ of the nannofossil assemblages. The last occurrence of Pseudoemiliania lacunosa is between Samples 133-823A-4H-4, $115 \mathrm{~cm}$, and $-4 \mathrm{H}-6,115 \mathrm{~cm}$. Rare specimens of this species were found in Samples $133-823 \mathrm{~A}-3 \mathrm{H}-3,115 \mathrm{~cm}$, and $-4 \mathrm{H}-2,115 \mathrm{~cm}$, and these rare and sporadic occurrences are considered reworked. The first occurrence of Gephyrocapsa spp. C-D (0.92 Ma) is in Sample 133-823A-9H-5, 115 $\mathrm{cm}$, where the species is common. The interval from Samples 133$823 \mathrm{~A}-9 \mathrm{H}-6,115 \mathrm{~cm}$, to $11 \mathrm{H}-2,116 \mathrm{~cm}$, contains mainly small Gephyrocapsa, with a virtual absence of large- or medium-sized Gephyrocapsa, and can be dated as 0.92 to $1.10 \mathrm{Ma}$. The highest occurrence of Gephyrocapsa spp. A-B (1.10 Ma) is in Sample 133-823C-11H-4, $116 \mathrm{~cm}$. The next datum recognized is the last occurrence of Helicosphaera sellii (1.27 Ma) in Sample 133-823C-12H-4, $116 \mathrm{~cm}$. Rare specimens of this species also were found in the next several samples (133-823A-12H-4, $116 \mathrm{~cm} ;-12 \mathrm{H}-5,116 \mathrm{~cm} ;-12 \mathrm{H}-\mathrm{CC} ;-13 \mathrm{H}-2,115$ $\mathrm{cm}$; and $-13 \mathrm{H}-\mathrm{CC})$. Rare specimens of Calcidiscus macintyrei were first encountered in Sample 133-823B-16X-CC. The CN13a/CN13b subzonal boundary $(1.48 \mathrm{Ma})$ thus can be drawn between Samples $133-823 \mathrm{~B}-16 \mathrm{H}-6,116 \mathrm{~cm}$, and $-16 \mathrm{H}-\mathrm{CC}$.

The highest Pliocene nannofossil datum, the last occurrence of Discoaster brouweri (1.88 Ma), is placed between Samples 133$823 \mathrm{~B}-18 \mathrm{X}-1,115 \mathrm{~cm}$, and $-18 \mathrm{X}-2,115 \mathrm{~cm}$. A succession of last occurrences of Discoaster pentaradiatus (2.29 Ma), Discoaster surculus (2.42 Ma), and Discoaster tamalis (2.6 Ma) occurs in Samples 133-823B-24X-3, $137 \mathrm{~cm},-25 \mathrm{X}-6,144 \mathrm{~cm}$, and $-26 \mathrm{X}-5,136 \mathrm{~cm}$, respectively. The last occurrence of Reticulofenestra pseudoumbilicus (3.51 Ma) lies in Sample 133-823B-38X-5, $126 \mathrm{~cm}$, where the species is represented by few specimens. This datum defines the CN11/CN12 zonal boundary, which corresponds to the lower Pliocene/upper Pliocene boundary.

The beginning of the acme of Discoaster asymmetricus (3.88 Ma) occurs in Sample 133-823B-45X-CC; this datum further divides Zone CN11 into Subzone CN11a and CN11b (Fig. 8). Rare specimens of Amaurolithus tricorniculatus were found in Sample 133-823B-55X$\mathrm{CC}$, thus the $\mathrm{CN} 11 / \mathrm{CN} 12$ zonal boundary $(4.24 \mathrm{Ma})$ can be placed 
Table 2. Occurrence of calcareous nannofossil species observed from Hole 822A.

\begin{tabular}{|c|c|c|c|c|c|c|c|c|c|c|c|c|c|c|c|c|c|c|c|c|c|c|c|c|c|c|c|c|c|c|c|c|}
\hline Age & $\begin{array}{c}\text { Nannofossil } \\
\text { zone/subzone }\end{array}$ & $\begin{array}{c}\text { Hole } 822 \mathrm{~A} \\
\text { Sample }\end{array}$ & 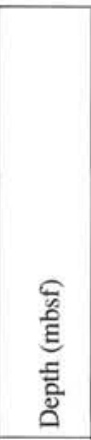 & 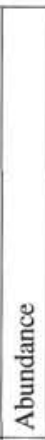 & 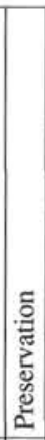 & 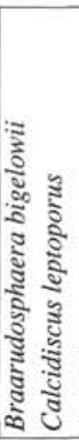 & 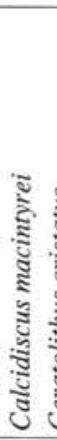 & & 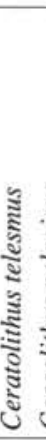 & & 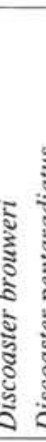 & 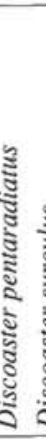 & & & 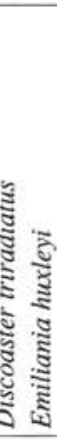 & & 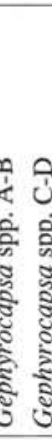 & 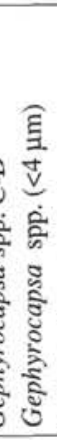 & 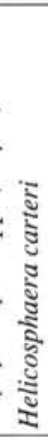 & 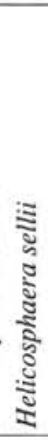 & 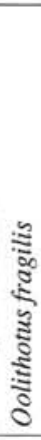 & 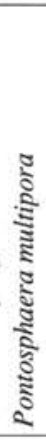 & 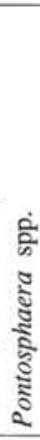 & 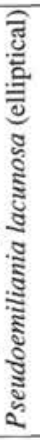 & 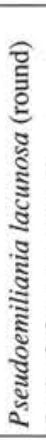 & 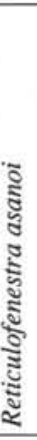 & 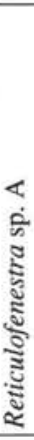 & 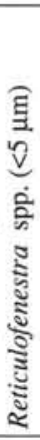 & 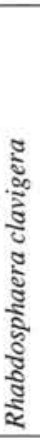 & 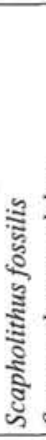 & 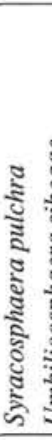 & 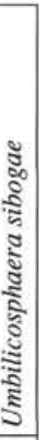 \\
\hline \multirow{52}{*}{ 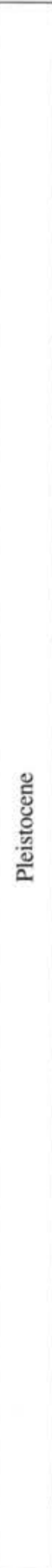 } & \multirow{11}{*}{ CN15 } & $1 \mathrm{H}-\mathrm{CC}$ & 0.90 & A & G & $\mathrm{F}$ & . & . & . & . & . & . & . & & C & . & A & A & $\mathrm{F}$ & . & . & . & . & . & . & . & . & . & . & . & . & C \\
\hline & & $2 \mathrm{H}-1,112-113$ & 2.02 & A & G & $\mathrm{F}$ & . & . & . & . & . & . & . & & . & & . A & A & R & . & . & . & $\mathrm{R}$ & . & . & . & . & . & . & R & $\mathrm{R}$ & F \\
\hline & & $2 \mathrm{H}-2,112-113$ & 3.52 & A & G & . $\mathrm{F}$ & .1 & $\mathbf{R}$ & . & . & . & & . & & A & & . $\mathrm{A}$ & $A$ & F & . & . & $R$ & $R$ & . & . & . & . & . & R & . & . & $\mathrm{R}$ \\
\hline & & $2 \mathrm{H}-4,112-113$ & 6.52 & A & G & . $\mathrm{R}$ & . & . & . & . & . & . & . & & $\mathrm{C}$ & & . $\mathrm{A}$ & $A$ & F & . & . & . & $R$ & . & . & . & . & . & R & . & F & $\mathbf{R}$ \\
\hline & & $2 \mathrm{H}-5,112-113$ & 8.02 & A & G & . $\mathrm{R}$ & . & . & & . & . & . & . & & $\mathrm{R}$ & & . $\mathrm{A}$ & $\mathrm{A}$ & R & & . & . & R & . & . & . & . & . & $R$ & & F & F \\
\hline & & $2 \mathrm{H}-6,112-113$ & 9.52 & A & G & . $\mathrm{R}$ & . & . & . & . & . & . & . & & $\mathrm{C}$ & & . $\mathrm{A}$ & $\mathrm{A}$ & $R$ & . & . & . & R & . & . & . & . & . & $R$ & & $\mathrm{~F}$ & F \\
\hline & & $2 \mathrm{H}-\mathrm{CC}$ & 10.40 & A & G & . $\mathrm{F}$ & . & . & . & . & . & & . & & A & & . $\mathrm{C}$ & $A$ & F & . & . & . & . & . & . & . & . & . & . & & R & F \\
\hline & & $3 \mathrm{H}-1,112-113$ & 11.52 & A & G & . $\mathrm{R}$ & . & . & . & . & . & . & . & & $\mathrm{R}$ & & . $\mathrm{A}$ & $\mathrm{A}$ & $\mathrm{R}$ & . & . & . & . & . & . & . & . & . & R & . & $R$ & . \\
\hline & & $3 \mathrm{H}-3,112-113$ & 14.52 & A & G & , $\mathrm{R}$ & . & . & . & . & . & , & . & & . $\mathrm{R}$ & & . $\mathrm{A}$ & $A$ & $\mathbf{R}$ & . & & $\mathrm{R}$ & . & . & . & . & . & . & . & . & R & $\mathrm{R}$ \\
\hline & & $3 \mathrm{H}-\mathrm{CC}$ & 19.90 & A & G & . $\mathrm{R}$ & . & . & . & . & . & . & . & & $\mathrm{C}$ & & . $\mathrm{A}$ & A & $\mathbf{R}$ & . & . & . & . & . & . & . & . & , & . & . & R & F \\
\hline & & $4 \mathrm{H}-1,113-114$ & 21.03 & $\mathrm{~A}$ & G & . $\mathrm{R}$ & . & . & . & . & . & . & . & & $\mathrm{R}$ & & . $\mathrm{A}$ & $\mathrm{A}$ & $\mathbf{R}$ & . & . & . & $\mathrm{R}$ & & . & . & . & . & . & & $\mathrm{R}$ & $\mathrm{F}$ \\
\hline & \multirow{21}{*}{$\mathrm{CN} 14 \mathrm{a}$} & $4 \mathrm{H}-2,113-114$ & 22.53 & A & G & . $\mathrm{R}$ & . & . & . & . & . & . & . & & . & & A & $A$ & $R$ & . & $R$ & . & $R$ & $R$ & . & . & . & . & . & $R$ & $\mathrm{~F}$ & \\
\hline & & $4 \mathrm{H}-3,113-114$ & 24.03 & A & G & . $\mathrm{R}$ & . & . & . & . & . & . & . & & . & & A & $\mathrm{A}$ & R & . & . & . & R & . & . & . & . & & . & . & R & \\
\hline & & $4 \mathrm{H}-4,113-114$ & 25.53 & A & G & . $\mathbf{R}$ & . & . & . & . & . & . & . & & . & & . $\mathrm{A}$ & $A$ & $R$ & . & . & $\mathrm{R}$ & R & $\mathrm{R}$ & . & . & . & . & . & & F & F \\
\hline & & $4 \mathrm{H}-\mathrm{CC}$ & 29.40 & A & G & . $\mathrm{C}$ & . & . & . & . & . & & . & & . & . & . $\mathrm{A}$ & $\mathrm{A}$ & $\mathbf{R}$ & . & . & . & . & $\mathbf{R}$ & . & . & & . & . & . & . & . \\
\hline & & $5 \mathrm{H}-\mathrm{CC}$ & 38.90 & A & M & . $\mathrm{R}$ & . & . & . & . & . & . & . & & . & & . $\mathrm{A}$ & $c$ & $\mathrm{R}$ & . & . & . & . & . & . & . & . & . & . & . & . & . \\
\hline & & $6 \mathrm{H}-\mathrm{CC}$ & 47.90 & A & G & . $\mathbf{F}$ & . & . & . & . & . & . & . & & . & & . $\mathrm{A}$ & $F$ & $\mathrm{R}$ & . & . & . & . & C & . & . & . & . & . & & F & C \\
\hline & & $7 \mathrm{H}-4,113-114$ & 54.02 & A & G & . $\mathrm{F}$ & . & . & . & . & . & . & . & & . & & . $\mathrm{A}$ & $\mathrm{A}$ & $\mathrm{R}$ & . & . & . & . & $\mathrm{R}$ & . & . & . & . & $\mathrm{R}$ & . & . & $\mathrm{F}$ \\
\hline & & $7 \mathrm{H}-5,113-114$ & 55.52 & A & G & . $\mathbf{F}$ & . & . & . & . & . & . & . & & . & & . $\mathrm{A}$ & $A$ & $\mathrm{~F}$ & . & . & . & . & $\mathrm{R}$ & . & . & $\mathrm{R}$ & . & $R$ & $\mathrm{R}$ & R & F \\
\hline & & 7H-CC & 57.90 & A & M & . $\mathrm{F}$ & & . & . & . & . & . & . & & . & & A & $A$ & F & . & . & . & . & C & . & . & $\mathrm{R}$ & . & $R$ & & R & F \\
\hline & & $8 \mathrm{H}-\mathrm{CC}$ & 67.40 & A & G & . $F$ & . & . & . & . & . & . & . & & . & & A & $A$ & F & . & . & & . & . & . & . & F & . & F & . & . & . \\
\hline & & $9 \mathrm{H}-\mathrm{CC}$ & 76.90 & $\mathrm{~A}$ & G & . $\mathrm{F}$ & & . & & & . & & . & & . & & . $\mathrm{A}$ & $\mathrm{A}$ & $\mathrm{F}$ & . & . & . & . & A & & . & $R$ & . & $\mathrm{F}$ & . & . & $\mathbf{R}$ \\
\hline & & $10 \mathrm{H}-2,114-115$ & 78.74 & A & G & . $\mathrm{R}$ & . & . & . & . & +. & . & . & & . & & . . & $\mathrm{A}$ & $\mathrm{R}$ & . & . & . & . & A & $\mathrm{C}$ & $R$ & $\mathrm{~F}$ & . & $R$ & $R$ & . & $R$ \\
\hline & & $10 \mathrm{H}-3,114-115$ & 80.24 & A & G & . $\mathbf{R}$ & . & . & . & . & & . & . & . & . & . & . & A & . & . & . & . & $R$ & A & C & . & F & . & . & . & & R \\
\hline & & $10 \mathrm{H}-\mathrm{CC}$ & 86.40 & A & G & . $\mathrm{F}$ & . & . & . & . & . & . & . & & . & . & . & A & R & . & . & . & . & A & . & . & R & . & $R$ & . & . & R \\
\hline & & $11 \mathrm{H}-3,111-112$ & 90.51 & A & G & . $\mathrm{F}$ & . & . & . & . & . & . & . & & . & . & . & A & $\mathrm{R}$ & . & . & $\mathrm{R}$ & R & A & $\mathrm{C}$ & . & R & . & R & . & . & $\mathbf{R}$ \\
\hline & & $11 \mathrm{H}-4,111-112$ & 92.01 & A & G & . $\mathrm{F}$ & . & . & . & . & . & . & . & & . & . & . & A & $\mathrm{F}$ & . & . & . & F & A & C & . & . & . & R & . & . & . \\
\hline & & $11 \mathrm{H}-5,111-112$ & 93.51 & A & G & . $\mathrm{R}$ & . 1 & R & . & . & . & . & . & & . & . & . & A & $\mathrm{F}$ & . & . & $\mathrm{R}$ & $R$ & A & C & . & . & . & $R$ & . & . & $\mathrm{R}$ \\
\hline & & $11 \mathrm{H}-\mathrm{CC}$ & 95.90 & A & G & . $\mathrm{R}$ & . & . & . & . & . & . & . & & . & . & . & A & F & . & . & . & . & A & . & . & . & . & . & . & . & $\mathbf{R}$ \\
\hline & & $12 \mathrm{X}-\mathrm{CC}$ & 104.21 & A & G & . $\mathrm{R}$ & & . & . & . & . & . & . & & . & . & . & A & $\mathrm{R}$ & . & . & . & . & A & . & . & . & . & . & & . & R \\
\hline & & $13 \mathrm{X}-\mathrm{CC}$ & 112.77 & A & G & . $\mathrm{F}$ & . & . & . & . & . & . & . & . & . & . & . & A & $\mathrm{R}$ & . & . & . & . & A & . & . & . & . & R & & $\mathrm{R}$ & F \\
\hline & & $14 \mathrm{X}-\mathrm{CC}$ & 122.97 & A & G & . $\mathrm{R}$ & .1 & R & . & . & . & . & . & . & . & . & . & A & $\mathrm{F}$ & . & . & . & R & A & . & . & . & . & . & . & R & F \\
\hline & \multirow[t]{20}{*}{$\mathrm{CN} 13 \mathrm{~b}$} & $15 X-1,112-113$ & 124.09 & A & G & . $\mathrm{R}$ & . & . & . & . & . & . & . & & . & c & . & A & $\mathrm{F}$ & . & . & . & $R$ & A & . & . & . & . & . & $\mathrm{R}$ & . & F \\
\hline & & $15 X-3,112-113$ & 127.09 & A & G & . $\mathrm{R}$ & & . & . & . & . & . & . & & . & F & . & A & R & . & . & . & R & A & . & . & . & . & $\mathbf{R}$ & . & . & $\mathrm{R}$ \\
\hline & & $15 \mathrm{X}-\mathrm{CC}$ & 132.19 & A & G & . $\mathrm{R}$ & . & . & . & . & . & . & . & & . & $\mathrm{c}$ & . & A & $\mathrm{F}$ & . & . & & R & A & . & . & . & . & . & $\mathrm{R}$ & . & F \\
\hline & & $16 \mathrm{X}-\mathrm{CC}$ & 139.92 & A & G & . $R$ & & . & . & . & . & . & . & & . & $\mathrm{F}$ & , & A & $\mathrm{R}$ & . & . & . & $\mathrm{R}$ & A & . & . & . & . & $\mathbf{R}$ & . & . & $\mathrm{R}$ \\
\hline & & 17X-CC & 154.00 & A & G & . $\mathbf{R}$ & . & . & . & . & . & . & . & & . & $c$ & . & A & $\mathrm{R}$ & . & . & . & R & A & & . & . & . & . & . & . & R \\
\hline & & $18 \mathrm{X}-\mathrm{CC}$ & 160.13 & A & G & . $\mathrm{R}$ & . & . & . & . & . & . & . & & . & F & . & A & $\mathrm{F}$ & . & . & . & . & A & . & . & t & & & . & . & $R$ \\
\hline & & $19 \mathrm{X}-2,112-113$ & 166.32 & A & G & . $\mathbf{R}$ & . & . & . & . & . & . & . & . & . & F & . & A & $\mathrm{F}$ & . & . & . & R & A & , & . & . & . & $\mathrm{R}$ & . & . & R \\
\hline & & $19 \mathrm{X}-3,112-113$ & 167.82 & A & G & . $\mathrm{F}$ & .1 & $\mathrm{R}$ & . & . & . & . & . & & . & F & . & A & $\mathrm{F}$ & . & . & . & $R$ & A & F & . & . & . & . & . & . & R \\
\hline & & $19 \mathrm{X}-\mathrm{CC}$ & 170.01 & A & G & . $\mathrm{F}$ & . & . & . & . & . & . & . & & . & $\mathrm{F}$ & . & A & $R$ & . & . & . & R & A & . & . & t & . & . & . & . & $\mathrm{R}$ \\
\hline & & 20X-CC & 182.60 & A & G & . $\mathrm{F}$ & . & . & R & . & . & . & . & & . & $\mathrm{F}$ & . & A & $\mathrm{R}$ & . & . & . & R & C & . & . & . & . & $R$ & . & . & R \\
\hline & & $21 \mathrm{X}-\mathrm{CC}$ & 191.72 & A & G & . $\mathrm{R}$ & . 1 & R & . & . & . & . & . & & . & $c$ & . & A & $\mathrm{R}$ & . & . & . & . & C & . & . & . & . & $\mathrm{R}$ & . & . & F \\
\hline & & $22 \mathrm{X}-\mathrm{CC}$ & 197.29 & A & G & . $\mathbf{R}$ & & . & & . & . & & . & & . & $c$ & . & A & $\mathrm{F}$ & . & . & . & . & A & . & . & . & . & F & & R & R \\
\hline & & 23X-CC & 206.53 & A & G & . $\mathbf{R}$ & . & . & . & . & & & . & & . & F & . & A & $\mathrm{F}$ & . & . & . & $R$ & A & . & . & . & . & R & & F & R \\
\hline & & $24 \mathrm{X}-\mathrm{CC}$ & 218.80 & A & G & . $\mathrm{F}$ & . & . & . & . & . & . & . & & . & c & . & A & $\mathrm{C}$ & . & . & . & $\mathrm{R}$ & A & . & . & . & . & R & & $R$ & $\mathrm{R}$ \\
\hline & & $25 \mathrm{X}-1,37-38$ & 221.27 & A & G & . $\mathrm{R}$ & . & . & . & . & . & . & . & & . & F & . & A & $\mathrm{F}$ & $\mathrm{R}$ & . & . & $R$ & A & . & . & . & . & $R$ & . & . & $R$ \\
\hline & & $25 X-3,37-38$ & 224.27 & A & G & . $\mathrm{R}$ & . & . & . & . & . & . & . & & . & F & . & $\mathrm{A}$ & $\mathrm{F}$ & $\mathrm{R}$ & . & & R & A & . & . & . & & R & . & . & $\mathrm{R}$ \\
\hline & & $25 \mathrm{X}-\mathrm{CC}$ & 229.02 & A & G & . $\mathrm{F}$ & . & . & . & . & . & 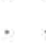 & . & . & . & F & . & A & C & $\mathrm{R}$ & . & . & $R$ & C & . & , & . & . & . & . & F & $R$ \\
\hline & & 26X-CC & 235.78 & A & G & . $\mathbf{R}$ & . & . & . & . & . & . & . & & . & $\mathrm{F}$ & . & A & $\mathrm{F}$ & . & . & . & . & C & . & . & . & . & R & . &. & . \\
\hline & & $27 \mathrm{X}-\mathrm{CC}$ & 249.13 & A & G & . $\mathbf{R}$ & . & . & . & . & . & & . & & . & $\mathrm{F}$ & . & A & R & . & . & . & . & F & . & . & & & . & . & . & . \\
\hline & & $28 \mathrm{X}-\mathrm{CC}$ & 256.10 & A & G & . $F$ & & & & & & & & & & & F & A & $\mathrm{F}$ & . & & . & & C & . & . & & & & & & \\
\hline
\end{tabular}

Note: $\mathrm{G}=$ good, $\mathrm{M}=$ moderate, $\mathrm{A}=$ abundant, $\mathrm{C}=$ common, $\mathrm{F}=$ few, and $\mathrm{R}=$ rare. 
Table 2 (continued).

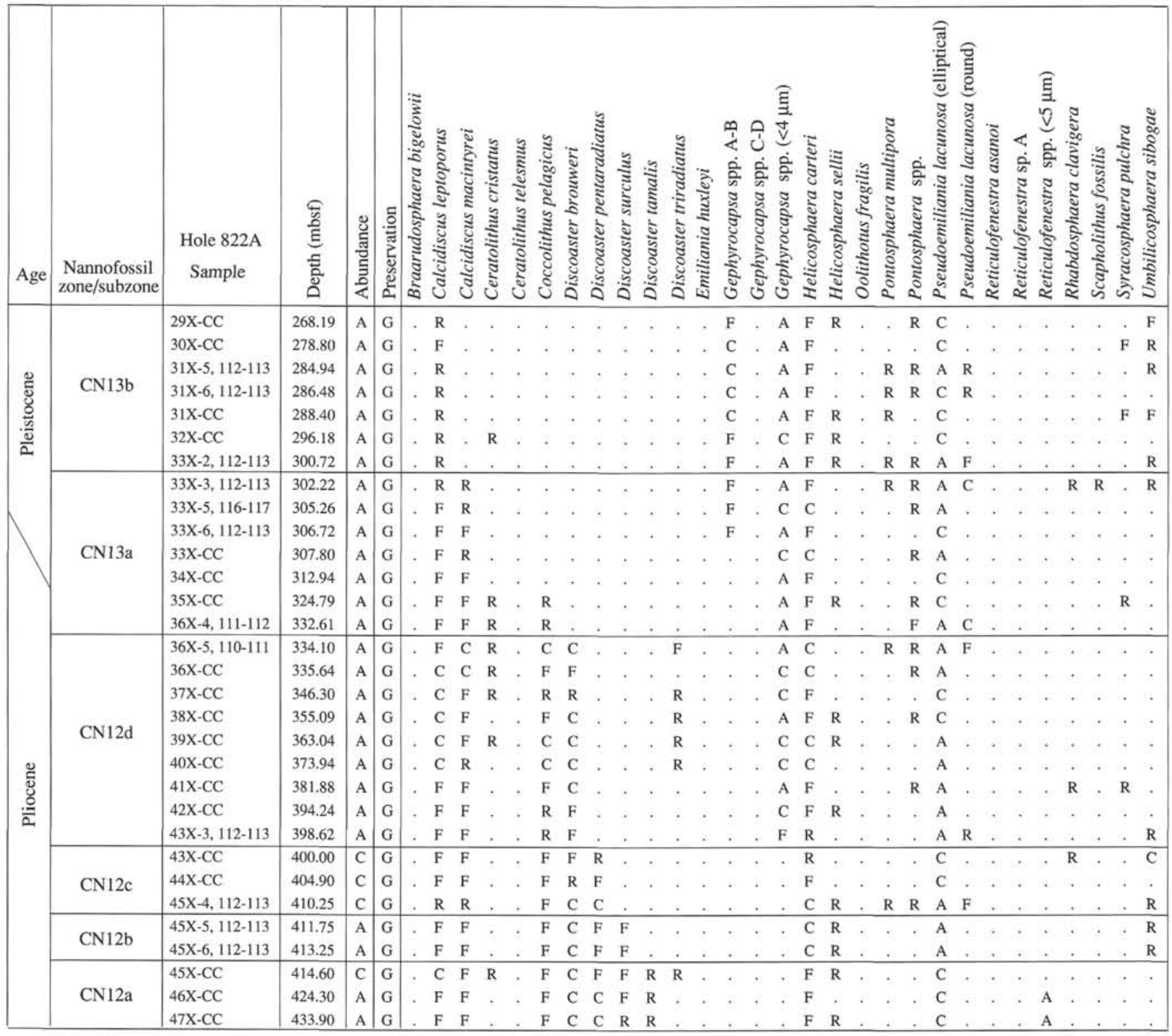

between Samples 133-823B-54X-CC and -55X-CC. However, this zonal boundary is considered very tentative because Amaurolithus tricorniculatus is very rare at Site 823 and was found in only one sample. The last occurrence of Ceratolithus armatus (4.6 Ma) is between Samples 133-823B-63X-5, $125 \mathrm{~cm}$, and $-63 \mathrm{X}-\mathrm{CC}$, and the first occurrence of this species (5.06 Ma) is between Samples 133823B-66X-CC and $-67 \mathrm{X}-1,134 \mathrm{~cm}$.

The last occurrence of Discoaster quinqueramus (5.26 Ma), which corresponds to the Miocene/Pliocene boundary, occurs between Samples 133-823B-69X-1, $135 \mathrm{~cm}$, and $-69 \mathrm{X}-2,135 \mathrm{~cm}$. Very rare specimens of Amaurolithus amplificus occur in Samples 133-823B-77X-CC, -78X$\mathrm{CC},-80 \mathrm{X}-3,125 \mathrm{~cm}$, and $-80 \mathrm{X}-\mathrm{CC}$. This suggests an age of lower Subzone CN9b (5.6 to 5.9 Ma) for these samples. Amaurolithus delicatus/Amaurolithus primus is very rare and its occurrence is very sporadic. It is not possible to use its first occurrence to subdivide Zone CN9 into $\mathrm{CN} 9 \mathrm{a}$ and $\mathrm{CN} 9 \mathrm{~b}$ at Site 823.

The first occurrence of Discoaster quinqueramus/Discoaster berggrenii $(8.2 \mathrm{Ma})$ is placed between Samples 133-823C-19R-CC and $-20 \mathrm{R}-1,118 \mathrm{~cm}$. Rare specimens of Catinaster calyculus occur in Sam- ples 133-823C-20R-5, $117 \mathrm{~cm}$, through -22R-4, $128 \mathrm{~cm}$; ages of $8.75 \mathrm{Ma}$ and $10.0 \mathrm{Ma}$ are assigned to these two samples respectively. Rare to few specimens of Catinaster coalitus occur from Samples 133-823C-22R-3, $137 \mathrm{~cm}$, through -24R-2, $125 \mathrm{~cm}$; this suggests an age range of 9.0 to 10.8 $\mathrm{Ma}$ for this stratigraphic interval. The lowest two samples from Site 823 (Samples 133-823C-24R-2, $125 \mathrm{~cm}$, and -24R-CC) contain poorly preserved nannofossils, which include Calcidiscus macintyrei, Coccolithus pelagicus, Discoaster brouweri, Helicosphaera sp., Reticulofenestra pseudoumbilicus, and Reticulofenestra minuta/Reticulofenestra minutula. These samples are probably younger than $11.0 \mathrm{Ma}$, based on the absence of Cyclicargolithus floridanus, a common species in middle Eocene-middle Miocene sediments.

A most remarkable feature of Site 823 sediments is that, although the sequence contains more than 1860 gravity flows (Davies, McKenzie, Palmer-Julson, et al., 1991), the succession of the nannofossil datums is still in order, and reworking of nannofossils is undetectable in virtually all the samples examined. This suggests that the gravity flow was a penecontemporaneous redeposition process, which did not involve sediments of markedly older ages. 


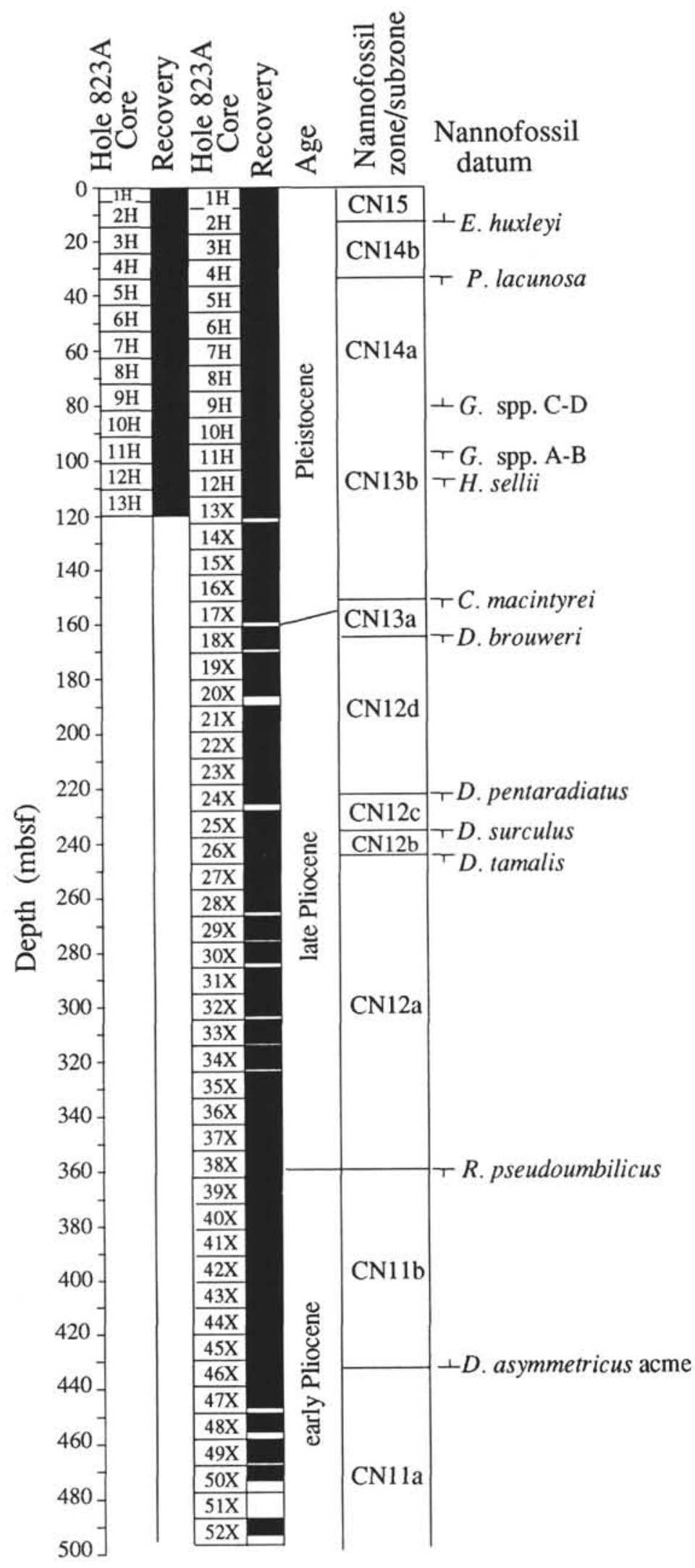

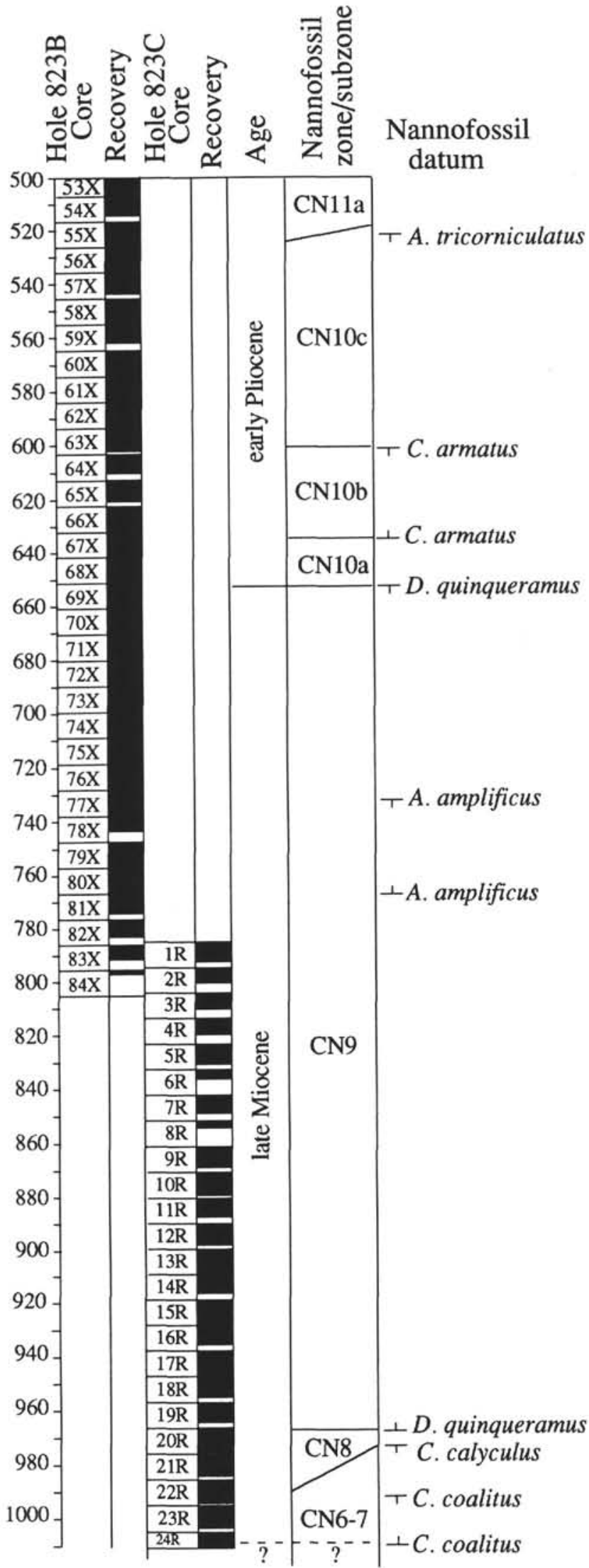

Figure 8. Calcareous nannofossil biostratigraphy, Site 823 . 


\section{Site 824}

Four holes were drilled at Site 824. Calcareous nannofossils are generally rare and poorly preserved at this site and are marginally useful for dating the upper Pleistocene to the middle Miocene sediments (Fig. 9).

Both Emiliania huxleyi and Pseudoemiliania lacunosa are absent in Samples 133-824B-1H-CC through -5H-CC; this interval is therefore assigned to Subzone $\mathrm{CN} 14 \mathrm{~b}$. Rare specimens of $P$. lacunos $a$ were first observed in Sample 133-824B-6H-CC, and this sample is older than $0.465 \mathrm{Ma}$. The true last occurrence of $P$. lacunosa may be stratigraphically higher but cannot be identified because nannofossils are scarce and preservation is poor. The next datum recognized is the last occurrence of Calcidiscus macintyrei (1.48 Ma) in Sample 133-824A$5 \mathrm{H}-\mathrm{CC}$. Sample 133-824A-6H-CC contains Discoaster pentaradiatus and is older than $2.29 \mathrm{Ma}$. Common Discoaster quinqueramus occur in Sample 133-824A-4H-CC; this sample has a minimum age of 5.26 Ma. Common Cyclicargolithus floridanus were found in Sample 133-824A-32X-CC. As no sediment was recovered in the seven cores above this level, the stratigraphic level for the last occurrence of $C$. floridanus (11.0 Ma) is unknown. No datable nannofossil assemblages were recovered below Core $824 \mathrm{~A}-32 \mathrm{X}$.

\section{Site 825}

Site 825 was intended to occupy the same position as Site 811 to penetrate the basement rock that Site 811 did not reach. Two holes were drilled at Site 825. Calcareous nannofossils are few to rare and poorly preserved in the sediments recovered, except for Core 133$825 \mathrm{~A}-1 \mathrm{H}$. Biostratigraphic resolution is poor (Fig. 10) owing to a low species diversity and the general absence of age-diagnostic species.

Sample 133-825A-1H-1 yielded a Pleistocene assemblage, which includes abundant Gephyrocapsa caribbeanica. Both Emiliania huxleyi and Pseudoemiliania lacunosa are absent. This suggest an age of Subzone CN14b (0.275-0.465 Ma).

Specimens of Sphenolithus are present from Samples 133-825A$5 \mathrm{H}-\mathrm{CC}$ through $-12 \mathrm{X}-\mathrm{CC}$. This indicates that these samples are older than $3.45 \mathrm{Ma}$ (Zone CN11). Cyclicargolithus floridanus is present in Sample 133-825A-6H-CC, which should be older than CN6. Calcidiscus premacintyrei occurs in Sample 133-825A-11X-CC. The presence of this species constrains the sample to an age range of 12.2-14.1 Ma (CN4-CN5).

No sediment was recovered from Cores 133-825A-13X through $-825 \mathrm{~B}-4 \mathrm{R}$ (Fig. 10). Samples from Hole $825 \mathrm{~B}$ contain virtually no age-diagnostic taxa. The presence of Cyclicargolithus floridanus in the samples, including Sample 133-825B-9R-1, $1 \mathrm{~cm}$, immediately above the metamorphic basement rock, indicates a broad age range of middle Eocene to middle Miocene.

\section{DIAGENESIS OF CALCAREOUS NANNOFOSSILS}

Preservation of calcareous nannofossils is generally good at Sites 209,822 , and 823; moderate at Sites 819 through 821; and poor at Sites 811,824 , and 825 . Examples of relatively well-preserved calcareous nannofossils from Site 822 can be seen in Plates 1 and 2 . Poorly preserved assemblages (Pl. 3) exhibit distinct calcite overgrowth and dissolution on most specimens. To better understand the diagenesis of calcareous nannofossils in the Great Barrier ReefQueensland Plateau transect sites, the mineralogical composition and calcium carbonate content at Sites 821 through 824 and 209 are compared (Fig. 11). Results from Sites 819 and 820 are similar to those from Site 821 , and results from Sites 811 and 825 are similar to those from Site 824. For simplicity, data from Sites $819,820,811$, and 825 are not presented in Figure 11.

A distinct feature in these periplatform carbonate sediments is that they contain a large amount of aragonite (Fig. 11) and high-magnesium calcite (see Davies, McKenzie, Palmer-Julson, et al., 1991), which is mostly derived from the carbonate platforms. Because aragonite and high-magnesium calcite are metastable, the sediments possess a high diagenetic potential (Schlanger and Douglas, 1974). Site 209 on the margin of the Queensland Plateau apparently received very little bank-derived material, and the sediments consist mainly of low-magnesium calcite contributed by calcareous nannofossils and foraminifers (Burns, Andrews, et al., 1973).

Figure 11 shows that the mineral compositions at Sites 821, 822, and 823 are generally similar except that the carbonate contents are slightly higher and noncarbonate (predominantly clay) contents are lower at Site 821. It has long been recognized empirically that nannofossil specimens in samples with high clay content are generally better preserved than those in carbonate oozes. The clay particles presumably have insulation effects on nannofossil specimens, inhibiting the diffusion necessary for the dissolution-diffusion-reprecipitation. The higher clay contents at Sites 822 and 823 thus contribute to the better preservation of the nannofossils there. Water depth is another factor that affects preservation. The most unstable minerals and least dissolutionresistant foraminifers and coccoliths are dissolved before burial at the relatively deep-water sites $(209,822$, and 823$)$. The assemblages thus have lower diagenetic potential. Besides water depth, the lack of bank-derived, metastable sediments at Site 209 accounts for the good preservation of nannofossils.

Sites 811,824 , and 825 differ significantly from Sites 819 through 823 in that they show consistently higher calcium carbonate contents (around $97 \%$ at Site 824, Fig. 11). This suggests that very little terrestrial material (clay and quartz) reached the Queensland Plateau. The lower silicate contents and abundant metastable minerals account for the poor preservation of nannofossils at these plateau sites.

Dissolution of aragonite and high-magnesium calcite and its consequent reprecipitation as low-magnesium calcite is relatively well known. Dissolution of low-magnesium calcite in shallow-water, shallow-burial carbonate sediments, however, is documented for the first time here (see Pl. 3) and discussed below.

The mineralogy of calcareous nannofossils has long been known as low-magnesium calcite (Siesser, 1977). The dissolution features of calcareous nannofossils thus are helpful for recognizing the dissolution of calcite, which otherwise would be difficult to recognize.

The species diversity and the abundance of calcareous nannofossils at Sites 811,824 , and 825 are very low. We ascribe this to the strong dissolution and overgrowth of the nannofossils. Both intense dissolution and overgrowth can be seen in Sample 133-824B-2H-1, $112 \mathrm{~cm}$ (Pl. 3), which is from $6.12 \mathrm{mbsf}$ and is of late Pleistocene age (0.28$0.47 \mathrm{Ma}$ ). This sample still contains abundant calcareous nannofossils and has far better preservation than samples farther downhole. Dissolution of calcite (indicated by arrow in Pl. 3) has caused fragmentation of many nannofossil specimens. This is surprising as aragonite needles are abundant in the sample ( $\mathrm{Pl} .3$ ). Aragonite needles are less stable than low-magnesium calcite and would be expected to dissolve before calcareous nannofossils.

The dissolved carbonate reprecipitates as secondary overgrowth on calcareous microfossils, including calcareous nannofossils. This process alters the appearance of nannofossils and, in extreme cases, makes identification of species impossible. For instance, the coccolith in Figure 2 (upper center) of Plate 3, the three coccoliths in Figure 3 of Plate 3, and the two coccoliths in Figure 4 of Plate 3 are so heavily overgrown that it is not possible to identify them even at the genus level.

\section{SUMMARY AND CONCLUSIONS}

Calcareous nannofossils are generally abundant in all Leg 133 sites, and they have provided the primary means of dating the sediments, particularly for the Pliocene-Pleistocene intervals.

Site 811 yielded abundant, moderately to poorly preserved nannofossils in the upper $230 \mathrm{~m}$ section. Ten nannofossil datums are useful for dating this middle Miocene through Pleistocene interval, and they 


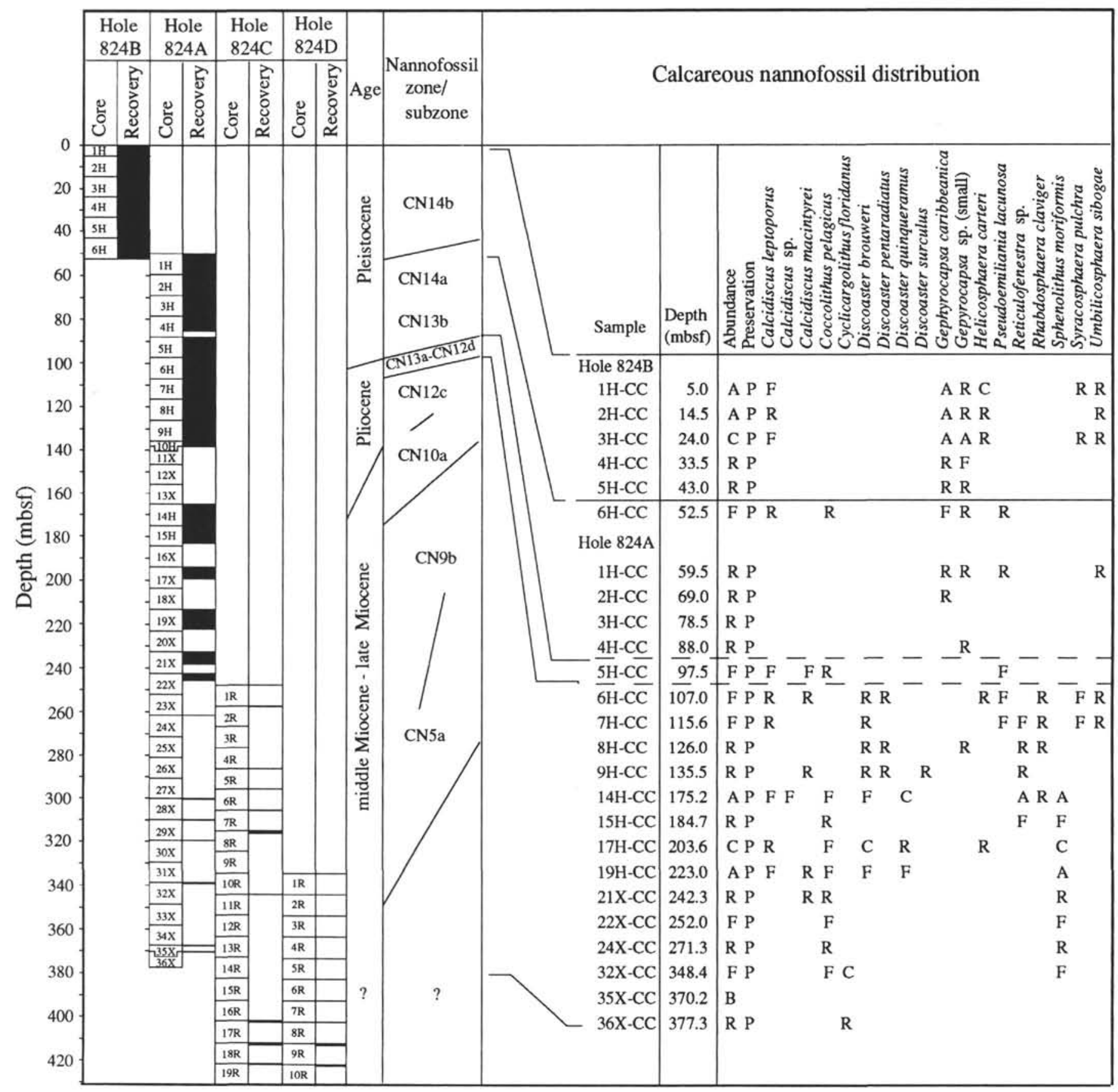

Figure 9. Occurrence of calcareous nannofossil species observed from Site 824. $\mathrm{P}=$ poor, $\mathrm{A}=$ abundant, $\mathrm{C}=$ common, $\mathrm{F}=$ few, $\mathrm{R}=$ rare, and $\mathrm{B}=$ barren.

suggest a fairly uniform sedimentation rate for this section. Nannofossils are rare or absent in the 230- to 380 -mbsf interval, where they provided minimal age information.

Site 819 yielded generally abundant, moderately well-preserved nannofossils throughout the 400 -m sequence. Six nannofossil datums are useful for biostratigraphy. The nannofossil stratigraphy suggests a very condensed interval or a hiatus in the middle Pleistocene. The oldest sediment recovered from this site is dated between $1.27 \mathrm{Ma}$ and $1.48 \mathrm{Ma}$.

Site 820 also yielded six nannofossil datums, and the oldest sediment is 1.27-1.48 Ma in age. No hiatuses or condensed intervals were detected.

Site 821 also contains abundant, moderately well-preserved nannofossils. Five nannofossil datums are available for dating this Pleisto- cene sequence. The bottom of the hole is older than $1.27 \mathrm{Ma}$, but younger than $1.48 \mathrm{Ma}$.

Site 822 yielded generally abundant, well-preserved nannofossils. Ten nannofossil datums have been determined in this Pliocene-Pleistocene sequence. A hiatus of more than $0.2 \mathrm{~m} . \mathrm{y}$. is detected in the middle Pleistocene. The oldest sediment at this site is between $2.6 \mathrm{Ma}$ and $3.5 \mathrm{Ma}$.

Generally abundant and well-preserved Holocene through upper Miocene nannofossils were recovered from Site 823. Twenty-two nannofossil datums have been recognized that provide a fairly highresolution biostratigraphy. A remarkable feature in this largely turbidite sequence is that all the nannofossil datums are in correct stratigraphic order and no extensive nannofossil redeposition is apparent in any of 


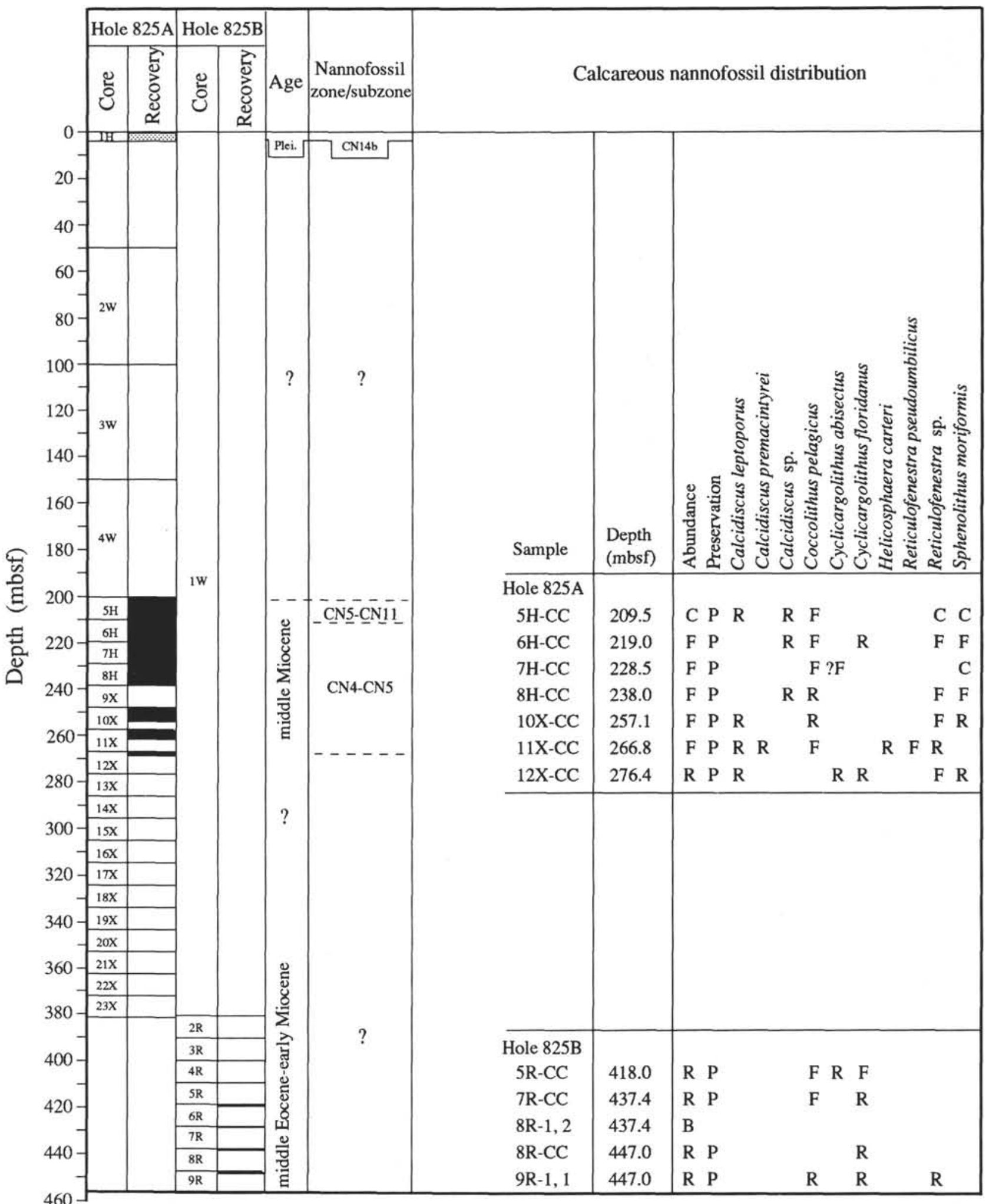

Figure 10. Occurrence of calcareous nannofossil species observed from Site 825. $\mathrm{P}=$ poor, $\mathrm{C}=$ common, $\mathrm{F}=$ few, $\mathrm{R}=$ rare, and $\mathrm{B}=$ barren.

the samples examined. This suggests a penecontemporaneous redeposition process, which did not involve significantly older sediments.

Nannofossils are abundant to absent and poorly preserved at Site 824. Biostratigraphic resolution is low, and only five nannofossil datums are useful for dating the Miocene through Pleistocene interval. Below 384 mbsf, no useful nannofossil age is possible.
Site 825 yielded virtually no age-diagnostic nannofossils, except in Cores 133-825 A-5H to -11X, which can be assigned to the middle Miocene.

Preservation of calcareous nannofossils varies greatly among different sites and is controlled by the amount of clay and bank-derived metastable aragonite and high-magnesium calcite in the sediments. 


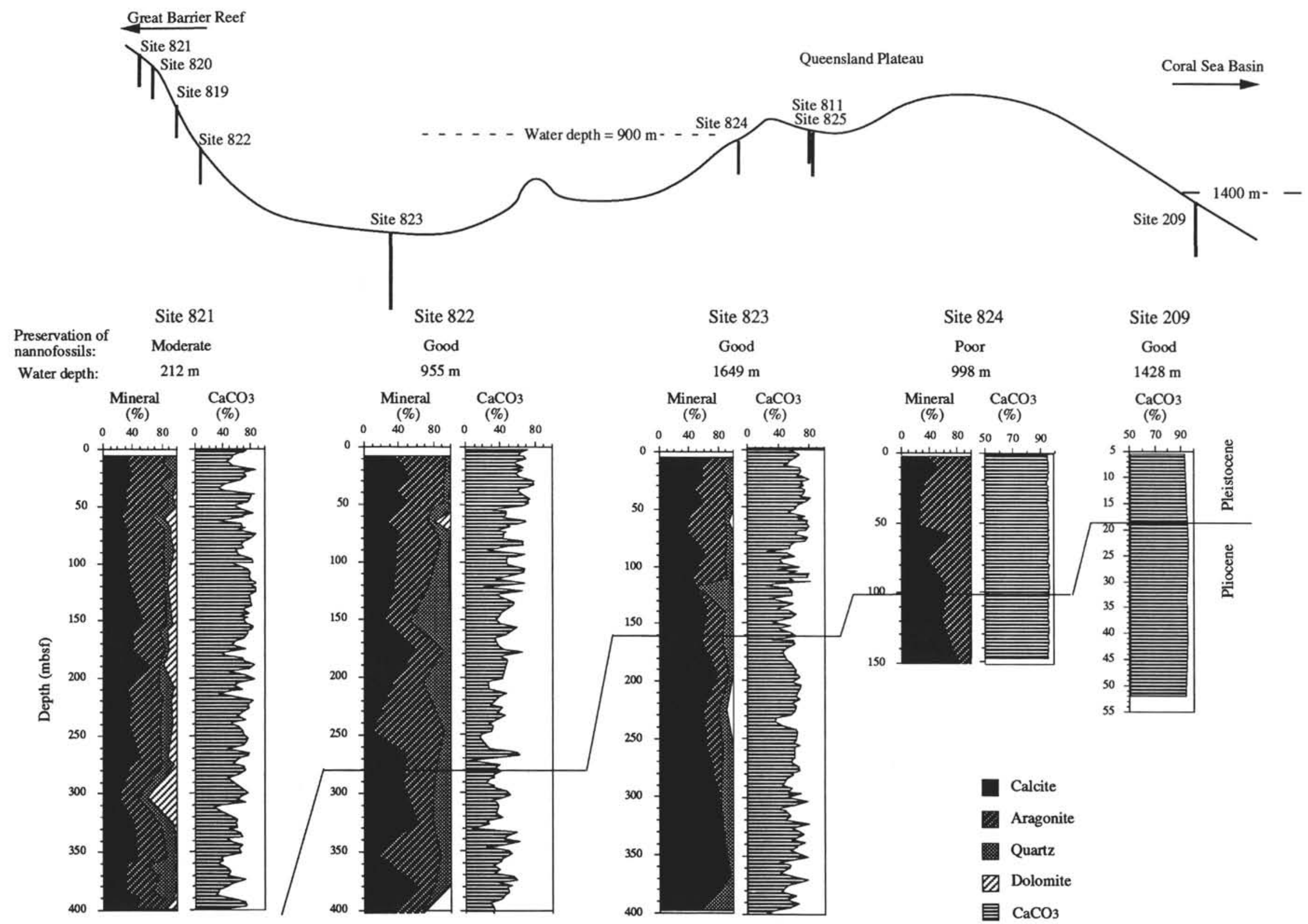

Figure 11. Schematic cross section showing sites investigated for diagenesis of calcareous nannofossils (upper panel); mineralogical composition (clays not included) and carbonate content for Sites 821 through 824 and 209 are shown in the lower panel (data from Davies, McKenzie, Palmer-Julson, et al., 1991; Burns, Andrews, et al., 1973). 
Strong dissolution of upper Pleistocene calcareous nannofossils deposited in relatively shallow water and buried at shallow depth is documented for the first time.

\section{ACKNOWLEDGMENTS}

We thank the crew of the JOIDES Resolution, the ODP technical staff, the Leg 133 Scientific Party, particularly P. Davies, J. McKenzie (Co-Chief Scientists), and A. Palmer-Julson (Staff Scientist) for an enjoyable and very successful cruise. We also thank T.J. Bralower and G. Olafsson for helpful reviews. Financial support of this study was provided by NSF Grant DPP91-18480 (S.W. Wise), USSAC grants, and NSF Grant OCE91-15786 (W. Wei).

\section{REFERENCES}

Berggren, W.A., Kent, D.V., and Van Couvering, J.A., 1985. The Neogene: Part 2. Neogene geochronology and chronostratigraphy. In Snelling, N.J. (Ed.), The Chronology of the Geological Record. Geol. Soc. London Mem., 10:211-260.

Burns, R.E., Andrews, J.E., et al., 1973. Init. Repts. DSDP, 21: Washington (U.S. Govt. Printing Office).

Davies, P.J., McKenzie, J.A., Palmer-Julson, A., et al., 1991. Proc. ODP, Init. Repts., 133: College Station, TX (Ocean Drilling Program).

Gartner, S., 1992. Miocene nannofossil chronology in the North Atlantic, DSDP Site 608. Mar. Micropaleontol., 18:307-331.

Loeblich, A.R., and Tappan, H., 1966. Annotated index and bibliography of the calcareous nannoplankton. Phycologia, 5:81-215.

- 1968. Annotated index and bibliography of the calcareous nannoplankton II. J. Paleontol., 42:584-598.

- 1969. Annotated index and bibliography of the calcareous nannoplankton III. J. Paleontol., 43:568-588.

, 1970a. Annotated index and bibliography of the calcareous nannoplankton IV. J. Paleontol., 44:558-574.

, 1970b. Annotated index and bibliography of the calcareous nannoplankton V. Phycologia, 9:157-174.

_ 1971 . Annotated index and bibliography of the calcareous nannoplankton VI. Phycologia, 10:315-339.

_ 1973. Annotated index and bibliography of the calcareous nannoplankton VII. J. Paleontol., 47:715-759.

Martini, E., 1971. Standard Tertiary and Quaternary calcareous nannoplankton zonation. In Farinacci, A. (Ed.), Proc. 2nd Int. Conf. Planktonic Microfossils Roma: Rome (Ed. Tecnosci.), 2:739-785.

Matsuoka, H., and Okada, H., 1989. Quantitative analysis of Quaternary nannoplankton in the subtropical northwestern Pacific Ocean. Mar. Micropaleontol., 14:97-118.

— 1990 . Time-progressive morphometric changes of the genus Gephyrocapsa in the Quaternary sequence of the tropical Indian Ocean. In Duncan, R.A., Backman, J., Peterson, L.C., et al., Proc. ODP, Sci. Results, 115: College Station, TX (Ocean Drilling Program), 255-270.

Matter, A., Douglas, R.G., and Perch-Nielsen, K., 1975. Fossil preservation, geochemistry and diagenesis of pelagic carbonates from the Shatsky Rise, northwest Pacific. In Larson, R.L., Moberly, R., et al., Init. Repts. DSDP, 32: Washington (U.S. Govt. Printing Office), 891-921.

Neugebauer, J., 1974. Some aspects of cementation in chalk. In Hsü, K.J., and Jenkyns, H.C. (Eds.), Spec. Publ. Int. Assoc. Sedimentol., 1:149-167.

Okada, H., and Bukry, D., 1980. Supplementary modification and introduction of code numbers to the low-latitude coccolith biostratigraphic zonation (Bukry, 1973; 1975). Mar. Micropaleontol., 5:321-325.

Roth, P.H., and Berger, W.H., 1975. Distribution and dissolution of coccoliths in the south and central Pacific. In Sliter, W.V., Bé, A.W.H., and Berger, W.H. (Eds.), Dissolution of Deep-Sea Carbonates. Spec. Publ. Cushman Found. Foraminiferal Res., 13:87-113.

Sato, T., Kameo, K., and Takayama, T., 1991. Coccolith biostratigraphy of the Arabian Sea. In Prell, W.L., Niitsuma, N., et al., Proc. ODP, Sci. Results, 117: College Station, TX (Ocean Drilling Program), 37-54.

Schlanger, S.O., and Douglas, R.G., 1974. The pelagic ooze-chalk-limestone transition and its implication for marine stratigraphy. In Hsü, K.J., and

\footnotetext{
"Abbreviations for names of organizations and publications in ODP reference lists follow the style given in Chemical Abstracts Service Source Index (published by American Chemical Society).
}

Jenkyns, H.C. (Eds.), Pelagic Sediments: On Land and Under the Sea. Spec. Publ. Int. Assoc. Sedimentol., 1:117-148.

Siesser, W.G., 1977. Chemical composition of calcareous nannofossils. S. Afr J. Sci., 73:283-285.

Steinmetz, J.C., 1985a. Bibliography and taxa of calcareous nannoplanktonV. INA Newsl., 7:5-28.

, 1985b. Bibliography and taxa of calcareous nannoplankton-VI. INA Newsl., 7:122-145.

, 1986. Bibliography and taxa of calcareous nannoplankton VIII. INA Newsl., 8:66-87.

1987a. Bibliography and taxa of calcareous nannoplankton-IX. INA Newsl., 9:6-29.

, 1987b. Bibliography and taxa of calcareous nannoplankton-X. INA Newsl., 10:81-109.

, 1988a. Bibliography and taxa of calcareous nannoplankton-XI. INA Newsl., 10:7-28.

, 1988b. Bibliography and taxa of calcareous nannoplankton-XII.

INA Newsl., 10:60-88.

, 1989. Bibliography and taxa of calcareous nannoplankton-XIII. INA Newsl., 11:6-23.

Takayama, T., and Sato, T., 1987. Coccolith biostratigraphy of the North Atlantic Ocean, Deep Sea Drilling Project Leg 94. In Ruddiman, W.F., Kidd, R.B., Thomas, E., et al., Init. Repts. DSDP, 94 (Pt. 2): Washington (U.S. Govt. Printing Office), 651-702.

van Heck, S.E., 1979a. Bibliography and taxa of calcareous nannoplankton. INA Newsl., 1:AB1-B27.

1979b. Bibliography and taxa of calcareous nannoplankton. INA Newsl., 1:ABV1-B42.

, 1980a. Bibliography and taxa of calcareous nannoplankton. INA Newsl., 2:5-34.

1980b. Bibliography and taxa of calcareous nannoplankton. INA Newsl., 2:43-81.

, 1981a. Bibliography and taxa of calcareous nannoplankton. INA Newsl., 3:4-41.

, 1981b. Bibliography and taxa of calcareous nannoplankton. INA Newsl., 3:51-86.

, 1982a. Bibliography and taxa of calcareous nannoplankton. INA

Newsl., 4:7-50.

1982b. Bibliography and taxa of calcareous nannoplankton. INA Newsl., 4:65-96,

, 1983. Bibliography and taxa of calcareous nannoplankton. INA Newsl., 5:4-13.

Winter, A., 1982. Post-depositional shape modification in Red Sea coccoliths. Micropaleontol., 28:319-323.

Wise, S.W., Jr., 1977. Chalk formation: early diagenesis. In Anderson, N.R., and Malahoff, A. (Eds.), The Fate of Fossil Fuel $\mathrm{CO}_{2}$ in the Oceans: New York (Plenum), 717-739.

\section{Date of initial receipt: 13 April 1992}

Date of acceptance: 19 November 1992

Ms 133SR-216

\section{APPENDIX}

List of species mentioned in the text, arranged in alphabetical order by generic epithets.

Amaurolithus amplificus (Bukry and Percival) Gartner and Bukry, 1975 Amaurolithus delicatus Gartner and Bukry, 1975

Amaurolithus primus (Bukry and Percival) Gartner and Bukry, 1975

Amaurolithus tricorniculatus (Gartner) Gartner and Bukry, 1975

Braarudosphaera bigelowii (Gran and Braarud) Deflandre, 1947

Calcidiscus leptoporus (Murray and Blackman) Loeblich and Tappan, 1978

Calcidiscus premacintyrei Theodorides, 1984

Calcidiscus macintyrei (Bukry and Bramlette) Loeblich and Tappan, 1978

Catinaster calyculus Martini and Bramlette, 1963

Catinaster coalitus Martini and Bramlette, 1963

Ceratolithus armatus Müller, 1974

Ceratolithus cristatus Kamptner, 1950

Ceratolithus telesmus Norris, 1965

Coccolithus pelagicus (Wallich) Schiller, 1930 
Cyclicargolithus floridanus (Roth and Hay) Bukry, 1971

Discoaster asymmetricus Gartner, 1969

Discoaster bellus Bukry and Percival, 1971

Discoaster berggrenii Bukry, 1971

Discoaster brouweri Tan emend. Bramlette and Riedel, 1954

Discoaster hamatus Martini and Bramlette, 1963

Discoaster pentaradiatus Tan emend. Bramlette and Riedel, 1954

Discoaster quinqueramus Gartner, 1969

Discoaster surculus Martini and Bramlette, 1963

Discoaster tamalis Kamptner, 1967

Discoaster triradiatus Tan, 1927

Discosphaera tubifer (Murray and Blackman) Ostenfeld, 1900

Emiliania huxleyi (Lohmann) Hay and Mohleri in Hay et al., 1967

Florisphaera profunda Okada and Honjo, 1973

Gephyrocapsa caribbeanica Boudreaux and Hay, 1969

Gephyrocapsa oceanica Kamptner, 1943

Gephyrocapsa protohuxleyi McIntyre, 1970
Helicosphaera carteri (Wallich) Kamptner, 1954

Helicosphaera sellii Bukry and Bramlette, 1969

Oolithotus fragilis Bramlette and Reinhardt, 1968

Pontosphaera multipora (Kamptner) Roth, 1970

Pseudoemiliania lacunosa (Kamptner) Gartner, 1969

Reticulofenestra asanoi Sato and Takayama, 1992

Reticulofenestra minuta Roth, 1970

Reticulofenestra minutula (Gartner) Haq and Berggren, 1978

Reticulofenestra pseudoumbilicus (Gartner) Gartner, 1969

Rhabdosphaera clavigera Murray and Blackman, 1898

Scapholithus fossilis Deflandre in Deflandre and Fert, 1954

Sphenolithus abies Deflandre in Deflandre and Fert, 1954

Sphenolithus moriformis (Brönnimann and Stradner) Bramlette and Wilcoxon, 1967

Syracosphaera pulchra Lohmann, 1902

Umbellosphaera irregularis Paache in Markali and Paasche, 1955

Umbilicosphaera sibogae (Weber-van Bosse) Gaarder, 1970 

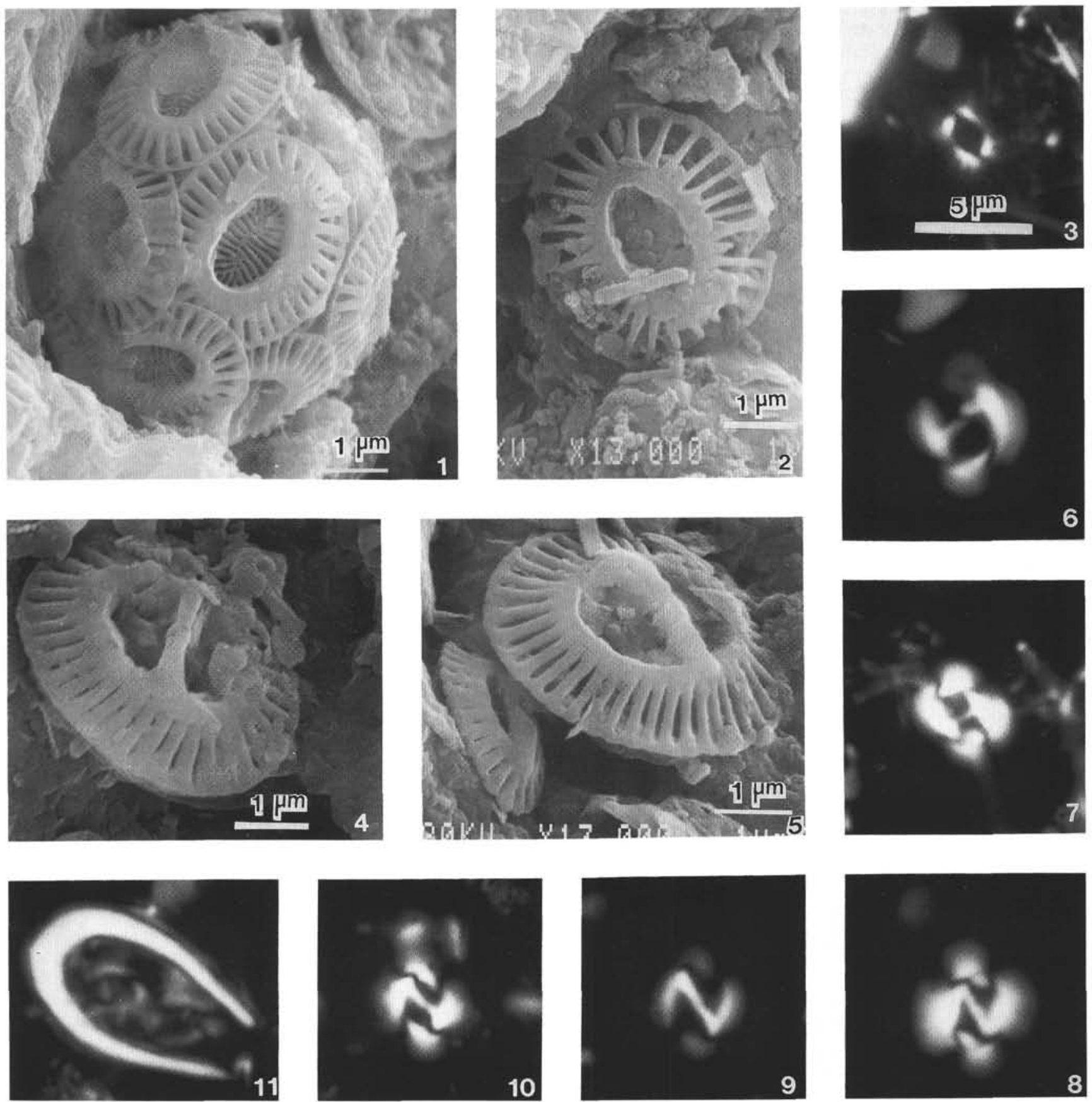

Plate 1. All light micrographs (3-11) are at the same magnification. 1-3. Emiliania huxleyi, Sample 133-822A-1H-CC. 4-5. Gephyrocapsa protohuxleyi, (4) Sample 133-822A-10H-2, 114 cm, (5) Sample 133-822A-11H-5, $111 \mathrm{~cm}$. 6-7. Gephyrocapsa sp. C Matsuoka and Okada (1990), Sample 133-822A-7H-5, $113 \mathrm{~cm}$. 8-10. Gephyrocapsa spp. A-B Matsuoka and Okada (1990). 11. Ceratolithus cristatus, Sample 133-822A-11H-5, 111 cm. 

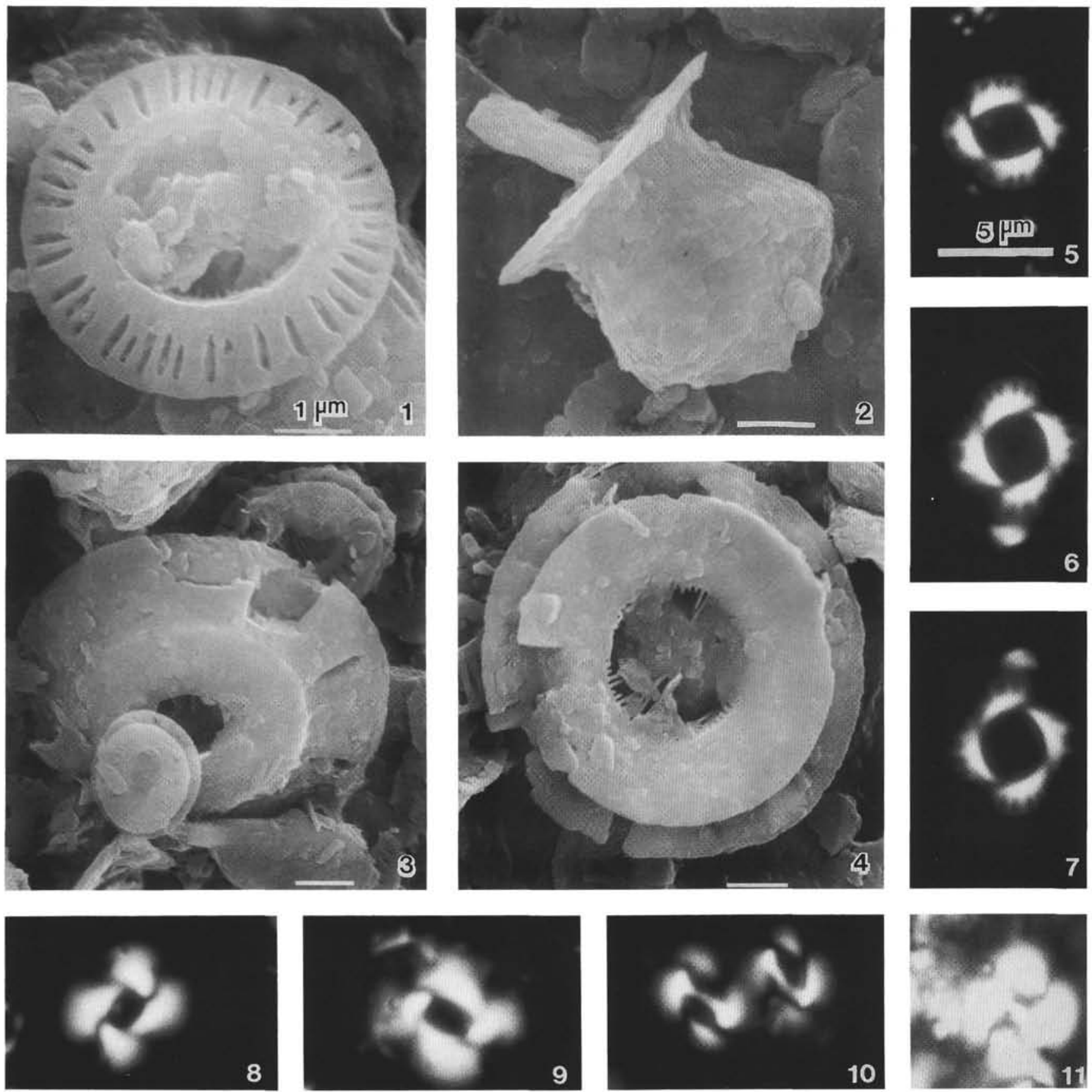

Plate 2. The scale bar for the SEM micrographs indicates $1 \mu \mathrm{m}$. All light micrographs are at the same magnification. 1, 5. Pseudoemiliania lacunose (elliptical type), Sample 133-822A-10H-2, 114 cm. 2. Discosphaera tubifer, Sample 133-822A-10H-4, 114 cm. 3, 8, 9. Reticulofenestra sp. A Takayama and Sato (1987), Sample 133-822A-10H-2, $114 \mathrm{~cm}$. 4. Reticulofenestra asanoi, Sample 133-822A-10H-2, $114 \mathrm{~cm}$. 6-7. Pseudoemiliania lacunosa (round type), Sample 133-822A-10H-2, $114 \mathrm{~cm}$. 10. Gephyrocapsa sp. B Matsuoka and Okada (1990), Sample 133-822A-24X-CC. 11. Gephyrocapsa sp. C Matsuoka and Okada (1990), Sample 133-822A-7H-5, $113 \mathrm{~cm}$. 

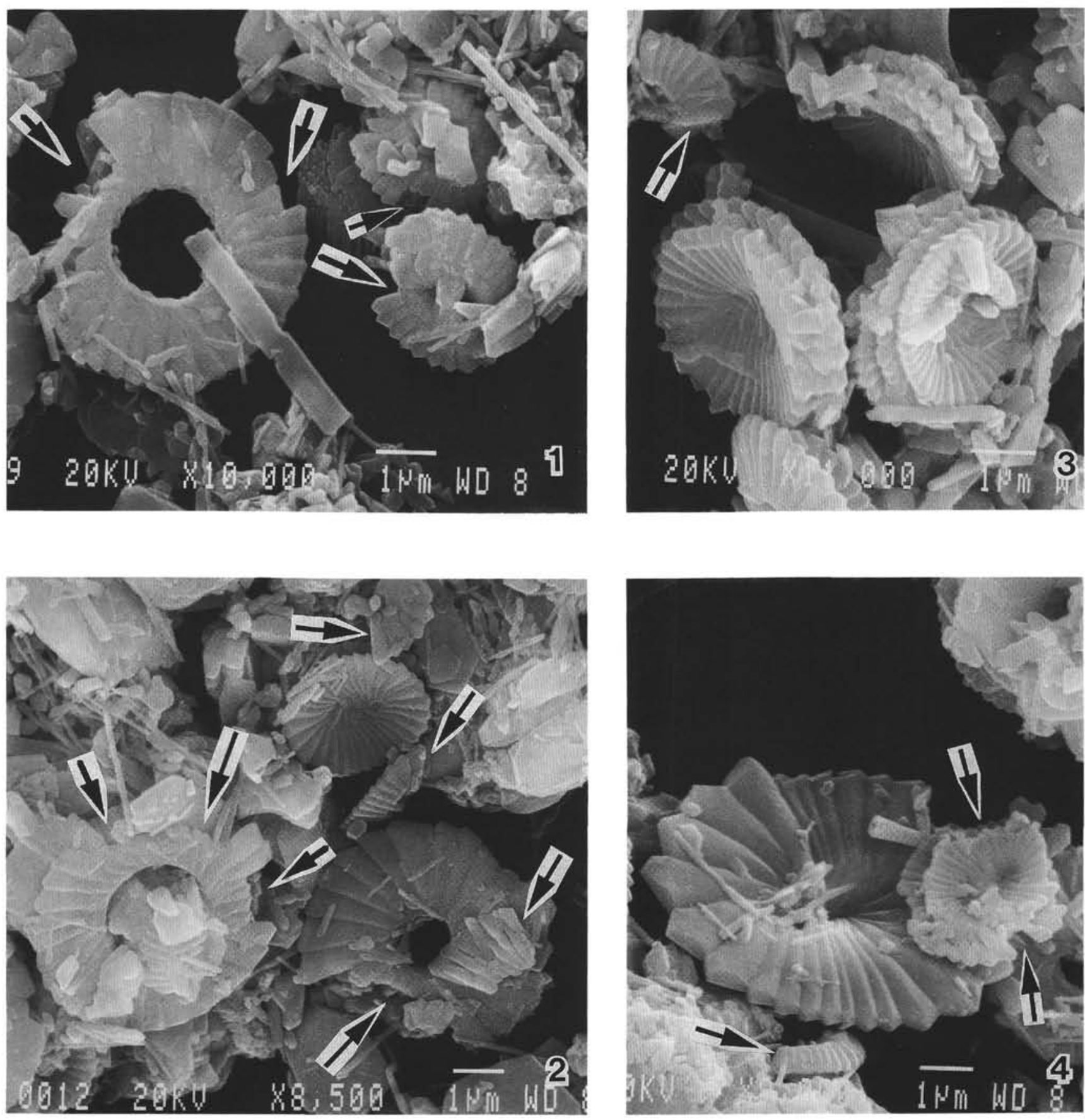

Plate 3. A nannofossil assemblage that shows strong dissolution (indicated by arrows) and overgrowth, Sample 133-824B-2H-1, 112 cm. Note that aragonite needles are abundant. 